\title{
النّص الحديثي
}

\section{يين القراءة التّفسيرية التّزامنية والقراءة المقاصدية المحيثية}

Medhet Korichi* $^{*}$

الملخّص

لا يمكن التّشكيك في نية كلّ ناقد لما في الصّّحاح من نصيوص حديثيّة لها صففة القلق

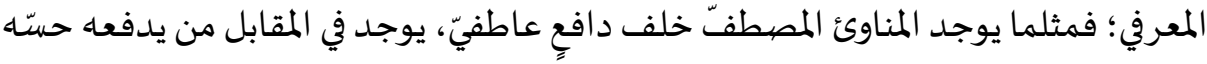

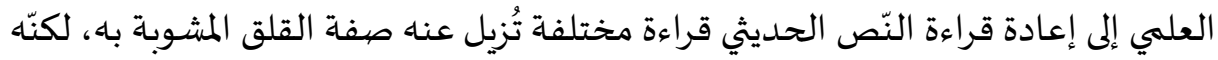

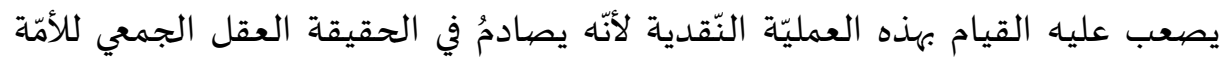

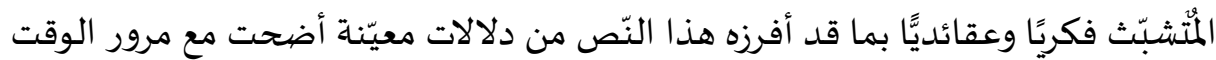

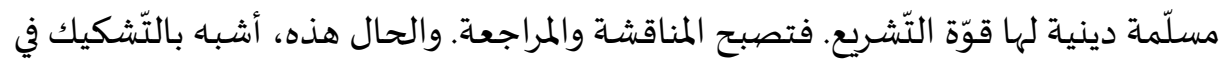

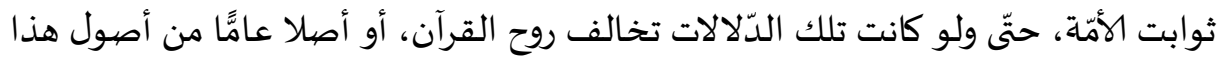

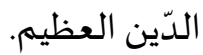

فما هي القراءة التّي يمكن الاعتماد عليها في تحليل النّص الحديثي من أجل المحافظة

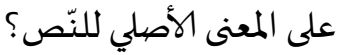

وهل يمكن أن يتأثّر النّص الحديثي بالفهوم البشرية اللاحقة لزمن الورود ؟

هذا البحث يؤسّس لقراءة جديدة لتلك الفئة من النّصوص، قراءة تعتمد على

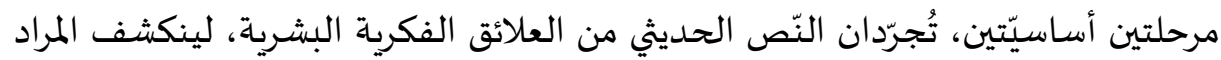

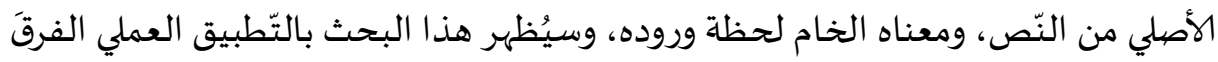

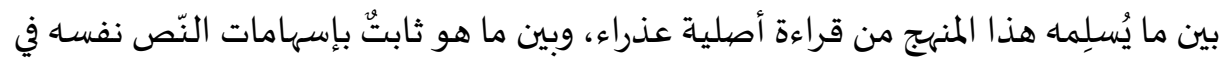
العقل الجمعي للأمّة.

الكلمات المفتاحية: النّص الحديثي، القراءة التّزامنية، القراءة التّأوبلية، الشُّؤم، المعنى

الأصلي، حدّ الردّة.

Doktora öğrencisi, Marmara Üniversitesi, İlahiyat Fakültesi, Tefsir Bölümü, Türkiye- Emir Abdulkadir Üniversitesi, Usulüddin Fakültesi, Kur'an İlimleri ve Tefsir Bölümü, Cezayir. e-posta : medhet07@gmail.com.

Makale Gönderim Tarihi: 07.08.2018

Makale Kabul Tarihi $\quad$ : 15.12.2018

NÜSHA, 2018; (47):269-308 


\section{HAZRET-İ PEYGAMBER'DEN SUDÛR ETTİĞİ DÖNEMİN IŞIĞINDA OKUMA İLE SONRAKİ DÖNEMLERE GÖRE OKUMA ARASINDA HADIS METNI}

\section{Öz}

Sahîhayn'da "bilgelik şüphesi” özelliğini taşıyan hadisler bulunduğundan hadisleri her eleştirenin niyetinden şüphe etmek mümkün değildir. Çünkü söz konusu şüphelerini ortadan kaldırma amaçlı farklı okumalar yapmak isteyenler de vardır. Fakat bu şahıslar, ümmetin kolektif aklıyla karşı karşıya geleceklerini düşünerek hadislere yaklaşımda fikirlerini ortaya koymaktan çekinirler. Zîrâ genel olarak milletin anlayışıında Kur'ân ruhuna veya dinin asıllarına muhalefet eden delaletleri dahi tartışmak ve bu delaletleri yeniden gözden geçirmek, ümmetin sabit temellerini ve kabul ettikleri inançlarını şüphe altında sorgulamakla eşdeğer görülür.

Peki, metnin orijinal anlamını korumak için hadis metninin güvenilir okuması nasıl olmalıdır ve hadis metni, ortaya çıktığı zamandan sonra oluşan insanlık anlayışından etkilenebilir mi?

$\mathrm{Bu}$ araştırma bu guruptaki metinlere dâir yeni bir okuma önerisine temel oluşturur. Söz konusu öneri iki ana aşamaya dayalı bir okumadır. $\mathrm{Bu}$ okuma, metnin orijinal anlamını ve ham anlamını ortaya çıkararak okuyanı şahsî fikirlerden büyük ölçüde arındırır.

Okuyacağınız makalede, orijinal okuma ile ümmetin kolektif zihnindeki anlayışlarıyla sabit olanlar arasındaki fark ortaya konulmaya çalışılmıştır. Eleştirel ve analitik düşünme metodunu uyguladığımız bu çalışmamız; giriş, iki bölüm ve sonuçtan oluşmaktadır.

Anahtar Kelimeler: Hadis metni, eş zamanlı okuma, yorumlayıcı okuma, uğursuzluk inanc1, özgün anlam, riddetin haddi.

\section{The prophetic text (Hadith) between the simultaneous interpretative reading and the objective reading}

\section{Abstract}

It's not possible in the term of examining a particular prophetic text or critizing its understanding to question everyone's intention toward it, just As there is who follows a motivational tendency when it came to studying those text, there is on the other hand who stands behind an 
intellectual motivation in attempt to re-read the prophetic text in its proper context, however this attempt of contextualize come in clash in reality with what can be called the common believe of the Umma who is deeply attached not only with the text itself as a sacred one but with the different interpretations which by the time become as indubitable as the text itself and then make the process of re-examine it as if it is an endeavor of skepticism towards one of the main pillars that represent the belief of the Umma, even when those interpretations it's not in conformity with the spirit of the Quran

This paper represents and set up a new methodology of re-read thoughtfully those debatable texts based on two essential steps: first is to free the text from different interpretations in order for the original intended meaning to be clear and then this study will also show in a practical manner the very different between this original methodological way of reading and the influence that shaped the common belief towards those texts.

Keywords: Al-Hadith text, Synchronous reading, Interpretative reading, Banshee, The original meaning, Apostasy

\section{Structured Abstarct}

Because it is the second source of legislation, and because it has a sanctity that is often comparable to the holiness of the Qur'anic text in terms of solicitude and validity, the prophetic narrations is constantly being subjected in every era to different readings and interpretations in order to benefit from it in practice, in the context of which it aims to protect that holiness and to preserve the very text from being contrary to reason, or to have a vulgar understanding.

These readings may carry the text of what is not to be tolerated, and may sometimes do justice it, and it may also take the text away from its original meaning of what the Prophet(peace and blessings of Allah be upon him) intended it, and we mean here of course by the prophetic tradition what was narrated from the Prophet (peace and blessings of Allah be upon him) in forms of utterance, actions or approved sign of something by him, not the moral qualities one because it does not attach to the practical legal rules as it is known. 
It is therefore, when we talk about the prophetic tradition in this context we definitely mean the authentic text which has been proved as such, This is to leave no doubt in its authenticity at the first apparent contradiction that may occur between the text and the reason, or between the text and the perceptivity (which is an endowment acquired by knowledge and faith), or between the text and what been recognized by human being as a shared standard based on common living.

Through my study of the prophetic traditions in terms of authenticity and the accurate knowledge of it, and also in term of understanding and applying. I came to notice that the prophetic tradition text is in need of two inseparable readings that guarantee the text two things:

1 - The prophetic meaning that the Prophet (pbuh) wanted to say when uttered the hadith at that time and that place with those circumstances, devoid of any subsequent human understanding; this is what the simultaneous interpretative reading does.

2 - Then benefit from the objectives (Maqasid) of that Hadith in successive time's as much as from the original interpretation or the prophetic primary intent. And that is what an objective reading does.

This research is aiming to establish an understanding of these two readings, which will divest the prophetic text from any human interfere in order for the original intent in the text to be revealed, and this research will demonstrate in practical application the difference between what this method of reading can present, and what is been considered as immutable understanding in common mind of Ummah

The research plan was as follows: An introduction, in which the question of research was mentioned in the following manner:

What is the reliable reading in the analysis of the prophetic text in order to preserve the original meaning of the it? And can the prophetic text influence by the human understanding after the time of the prophet?

Then I mentioned the goal of the research as well as the approach on which research is based which is here the critical analytical approach. I therefore made the first chapter as a theoretical discourse in which it was focus on clarifying the concept of simultaneous interpretative reading and objective reading. The second was devoted to 
the applied side, where the two readings mentioned above were applied on three authentic hadiths. Then I concluded the research with a conclusion where I mentioned the results of this study which include:

Any attempt to read the text in a deductive reading, without passing on a simultaneous interpretative reading is a circumvent from the original meaning of the Prophet saying (peace and blessings of Allah be upon him), and from the specific circumstance for being a reason of it initially. Thus, the simultaneous reading of the prophetic text is the basis for preserving the true prophetic intent as stated, based on its reading within its temporal and spatial framework and the general and detailed circumstances that accompanied the utterance of the text. Then it is possible to take advantage of the prophetic intention of the text as it is according to the new changes in reality in the context of an objective reading.

In addition to this, a truncated reading that is not in conformity with the general situational context in which the prophetic hadith was initially uttered lead many scholars to firm and legitimate convictions which are in fact contrary to the spirit of the Qur'an and the general fundamentals of Islam, such as the punishment of apostasy that can been seen as a clash of the freedom of religion and the fight of infidels for the reason of disbelieve, as well as the blemish belief in women and others, all of these may enhance the false beliefs that Islam has striven since the beginning of the prophetic call to remove it from the mentality of the Muslim community.

Also, one of the most important results is that the rejection of the authentic text that have been proven as so, because of the conceptual concern is may consider as an act which is costly and unjust toward that text, and it is practice that reflects a methodological weakness of the researcher's ability. However, any act that preserves this text from negligence it is indeed practices that present the strength of the researcher methodologically and knowledgeably which is to re-read the text again in order to remove any concern. It is the simultaneous interpretative reading that I have presented it in this research. 


\section{مقدّمة:}

يتعرّض النّص الحديثي ـ بشكل مستمرّ، وفي كلّ عصر ـ إلى قراءات وتفسيرات مختلفة

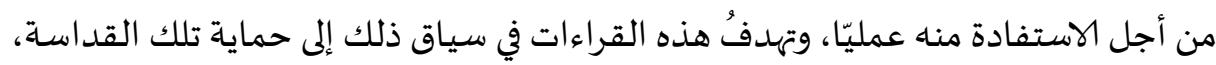
وصهون النّص ذاته من أن يناقض العقل، أو أن يكون محلّ فهم مبتذل. وندل.

وقد تُحمّل تلك القراءات النّص الحديثي ما لا يتحمّله، وقد تُنصفه أحيانًا، وأحيانًا

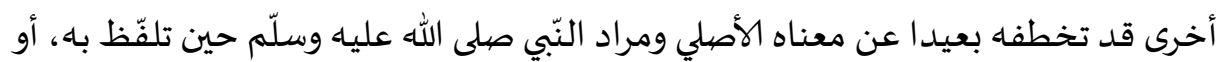

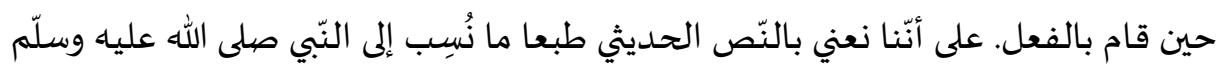

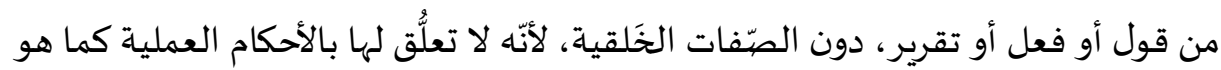
معلوم.

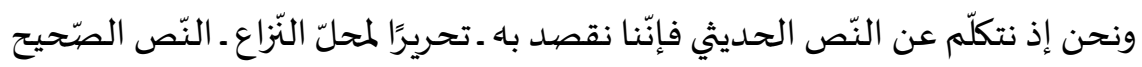

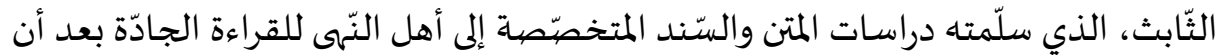

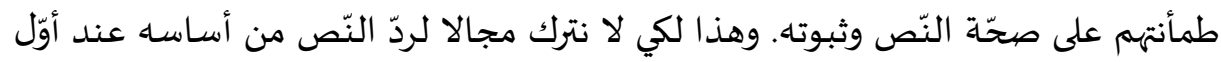

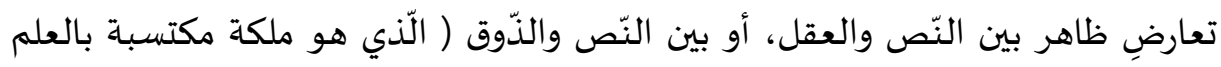

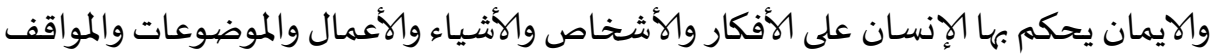

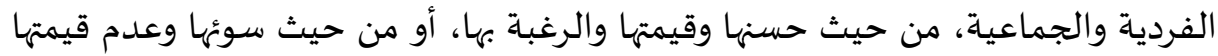

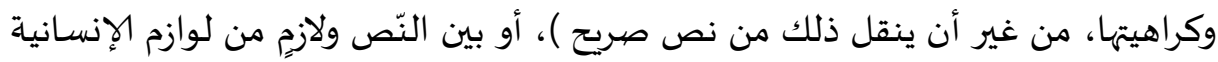

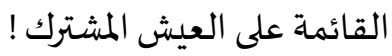

ومن خلال دراستي المتخصيّصة فيما يُعنى بالنّص الحديثي دراية ورواية، فهمًا وتطبيقًا؛

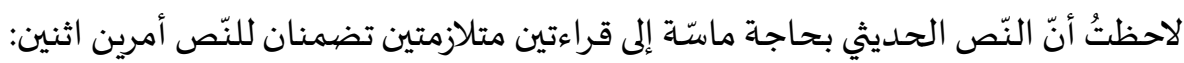
1 ـ المقصيود النّبوي الذي أراده صلى الله عليه وسلّم عندما تلفّظ بالحديث في ذلك

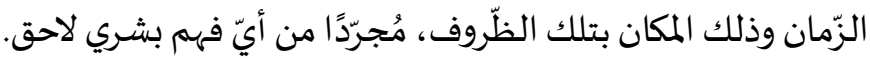
2 ـ الاستفادة بعد ذلك مقاصديًا من ذلك الحديث في الأزمنة المتعاقبة بقدر الطّاقة

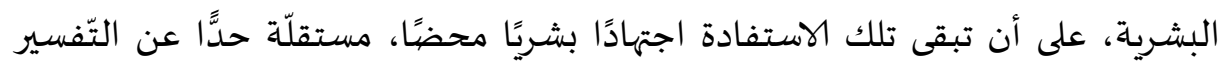
الأصلي أو ما عرف بالمقصود النّبوي الابتد تبئي تلئي.

المبحث الأوّل: التعريف بالقراءة التفسيرية التزامنية، والقراءة المقاصدية المثمرة: 


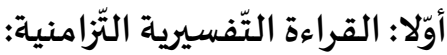

هي قراءة توضيحية تزامنية تراعي السّياق التّاريخي الزّمني والمكاني للنّص الحديثي،

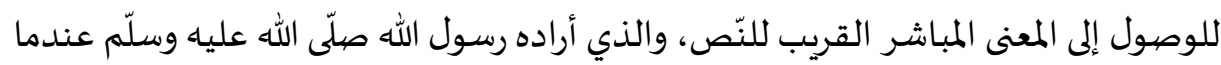

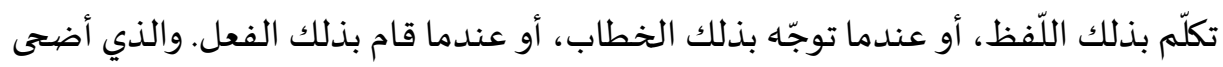

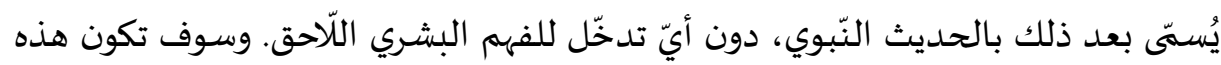

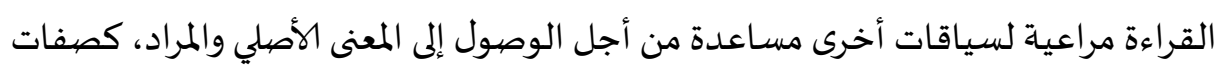

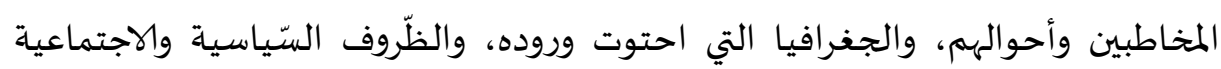

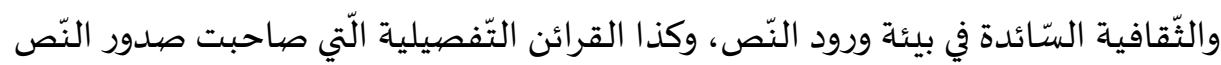

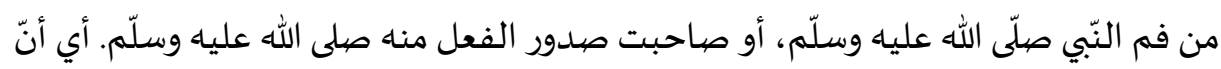
الباحث في هذه القراءة، يحاول قدر المستطاع أن يعيش أجواء وظروف ولادة النّص، وكأنّه كان حاضرًا لحظة وروده.

\section{ثانيا: القراءة المقاصيدية الإسقاطية:}

هي قراءة تأويلية مقاصيدية، ينطلق فيها الباحث من القراءة التفسيرية التّزامنية ليُعيد

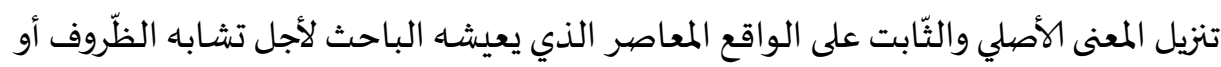

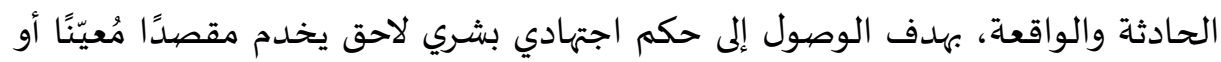

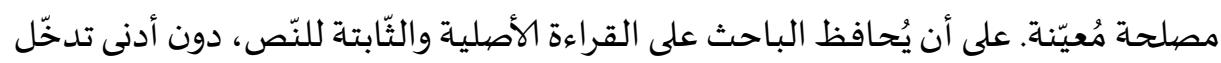
في المعنى الأصلي.

وتعتبر هذه القراءة قراءة مُثمرة، مُحِيَةًة للنّص الحديثي وخادمة له بشرط أن تعتمد

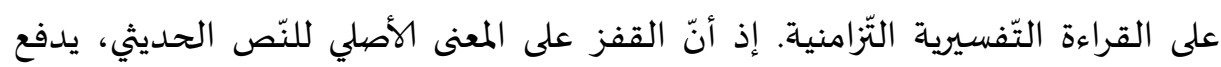

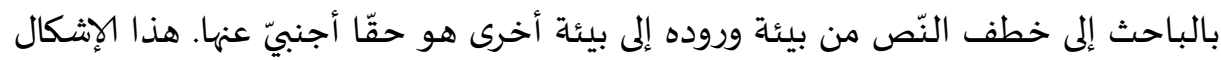

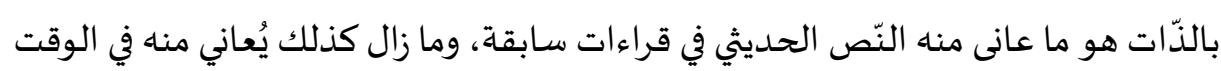
الرّاهن.

إنّ هذا التّأصيل يبقى بلا فائدة علمية مرجوة، إذا لم يُدَعَّم بأمثلة تطبيقية حيّة،

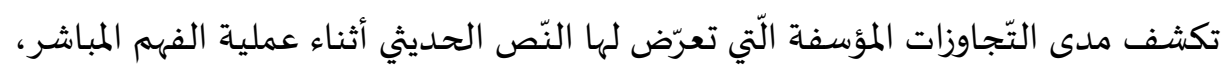


أو أثناء عملية استنباط الأحكام بعيدًا عن هاتين القراءتين المتلازمتين في الحقيقة. لهذا

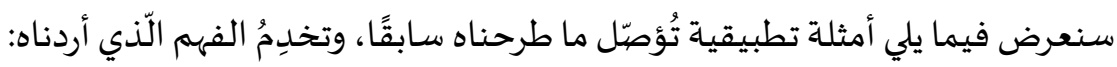

\section{المبحث الثاني: دراسة تطبيقية:}

1 ـ حديث الأمر بمقاتلة الناس حتى يشهدوا أن لا إله إلا الله:

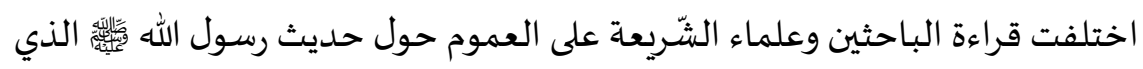

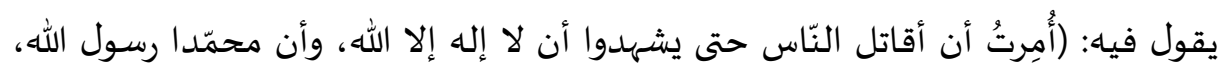

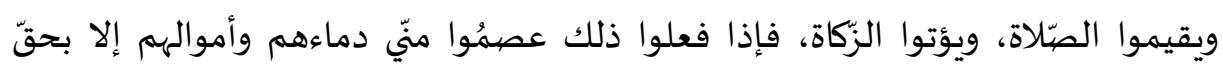

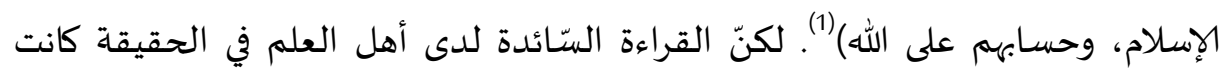

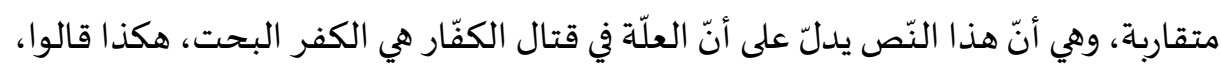

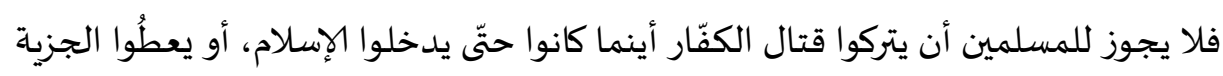
بالنسبة إلى أهل الكتاب كما أفادته آية التّوبة. إذن فالغاية التي ينتهي إليها قتال النّاس أو الكفّار أينما كانوا هي شهادة أن لا إله إلا إلا

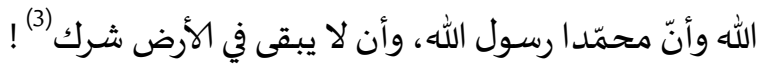

ثمّ عمَدوا إلى آياتٍ من كتاب الله تعالى، وفسّروها بهذا الحديث ضاربين صفحًا عن

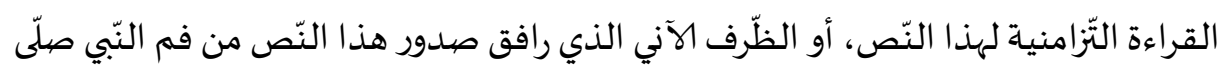

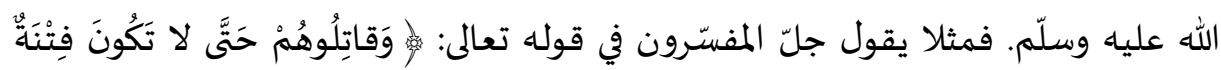

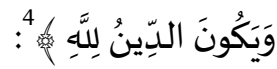

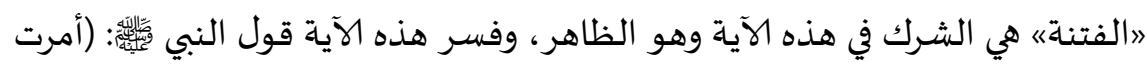

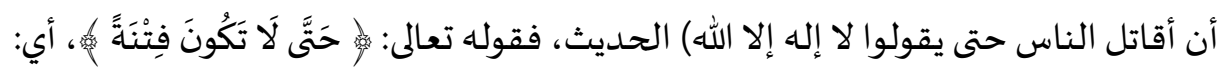

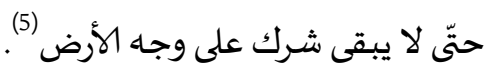

ويقول القرطبي بكلّ وضوح: ( قوله تعالى: "وقاتلوهم"، أمرّ بالقتال لكلّ مشرك في كل

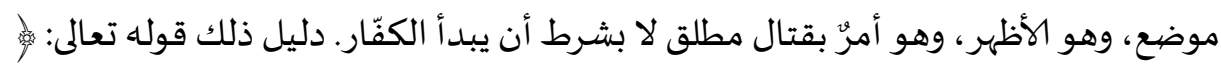

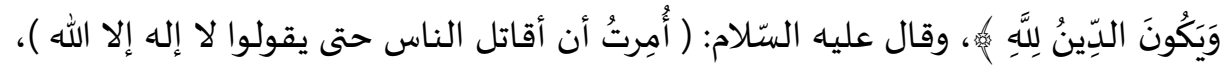

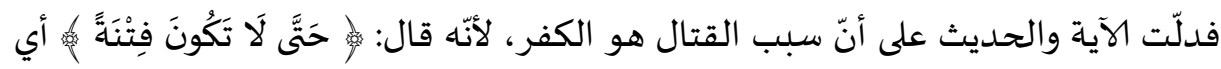

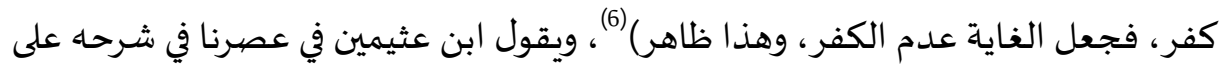


رياض الصيّالحين: (وعلى هذا فيقاتل الكفار إلى غايتين إما أن يسلموا وإما أن يعطوا الجزية

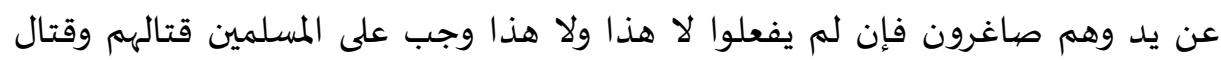

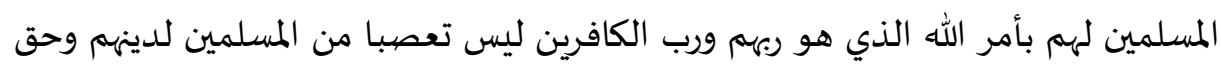

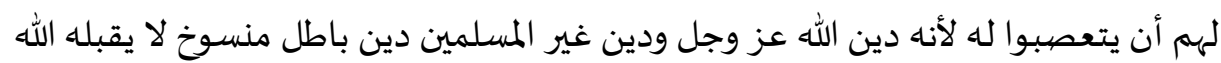

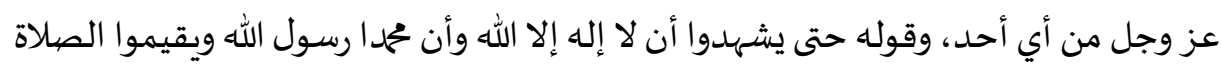

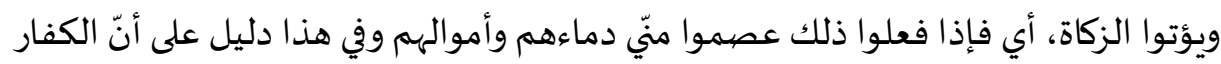

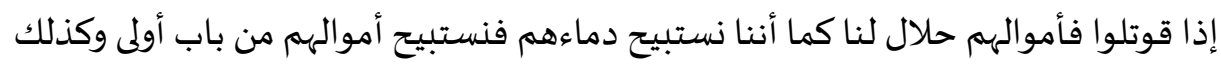

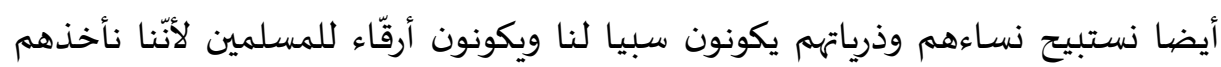

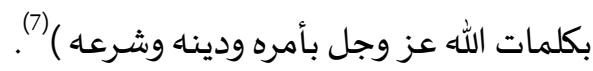

بل ذهب بعضهم إلى أبعد من ذلك؛ فاستدلّ بهذا الحديث على وجوب قتل المسلم تارك

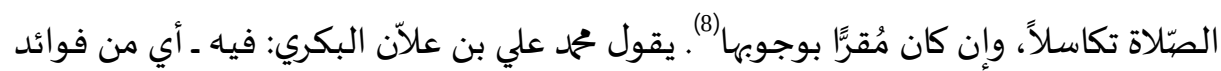

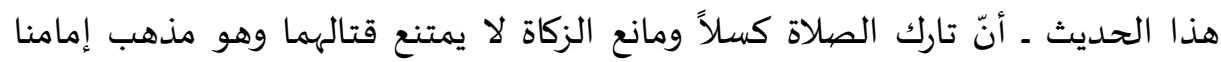

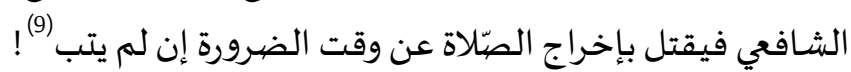

طيّب، هل يُعقل أنّ الله ـ جلّ وعلا _ـ أمر نبيّه م أن يُقاتل الكفّار جميعًا، أينما وُجدوا

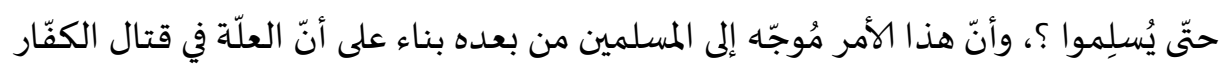

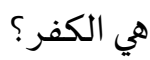
أليس هذا الفهه والاستنتاج الفقهي من أئمتنا يؤسّس لثقافة الحرب والعدوان بين

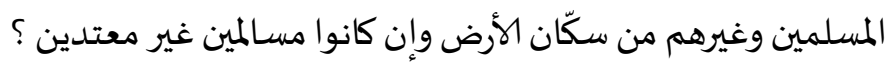
ألا تناقض هذه القراءة، ما تُؤسّسـها آيات القرآن في كلّ مرّة لحرّيّة التّديّن، واحترام

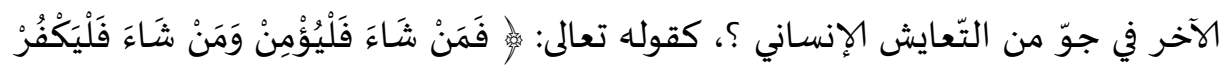

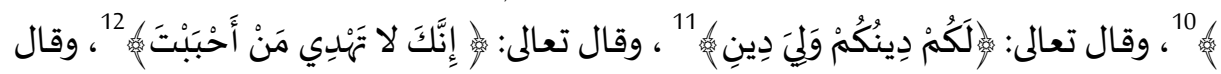

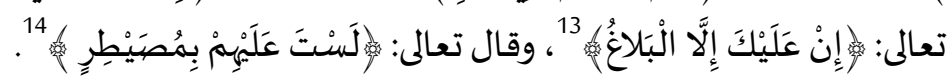

ماذا كان يقصد النّبي صهلّى الله عليه وسلّم بهذا الحديث إذن ومن كان يقصد؟ لَّك

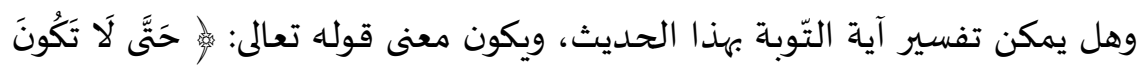

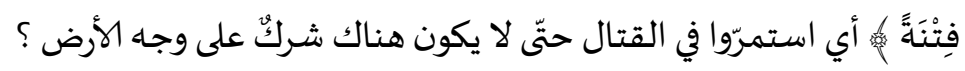


للإجابة على هذه الإشكالات الخطيرة في الحقيقة، لابدّ من ردّ هذا النّص الحديثي المهمّ

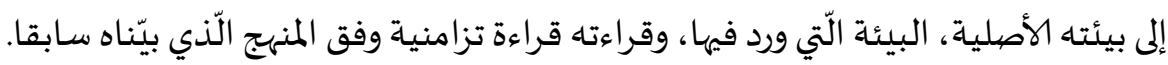

\section{1 - القراءة التّفسيرية التّامنية لهذا النّص:}

الظّاهر، بل ممّا لا شكّ فيه أنّ رسول الله م تلفّظ بهذا الحديث بعد إذن الله تعالى له

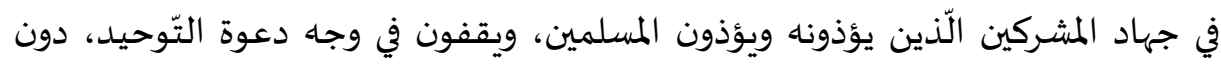

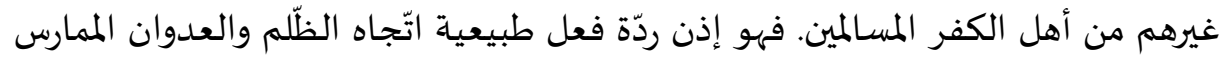

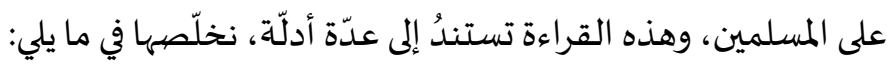

1 ـ تصريح الطّبري الدّقيق حول سبب ورود هذا الحديث، حيث قال إنّه عليه الصيّلاة

والسلام قاله في وقت قتاله للمشركين أهل الأوثان (15).

2 ـ تخصيص الرّواية الأخرى التّي عند النّسائي لفظ "النّاس" بلفظ "المشركين" على

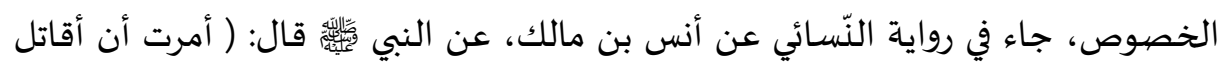

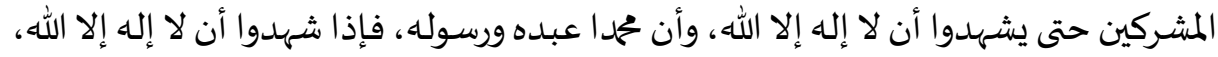

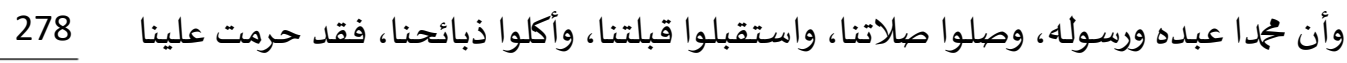

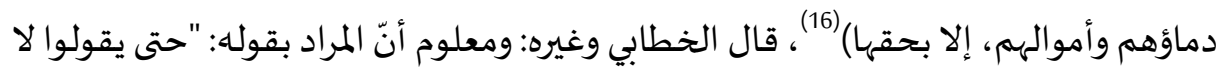

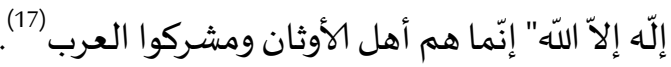

3 ـ لم يردنا ولا رواية واحدة، أنّ رسول الله صيلّى الله عليه وسلّمم ابتدأ قوما بالقتال لعلّة

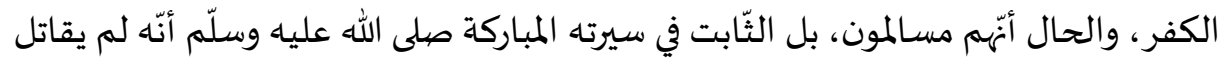

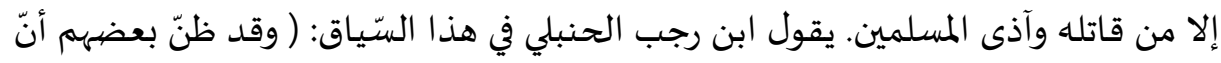

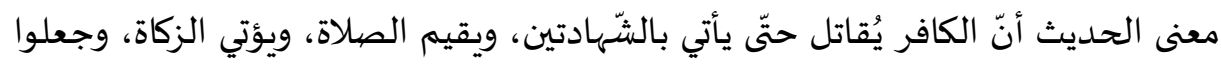

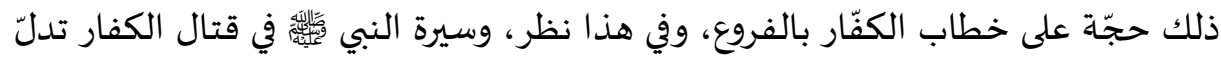
على خلاف هذا) (18).

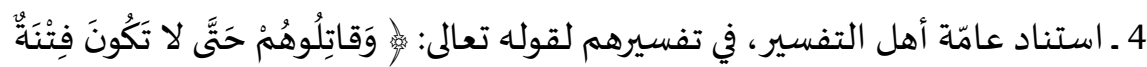

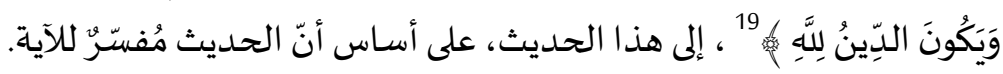

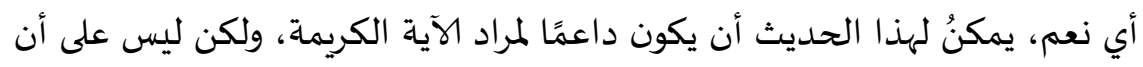

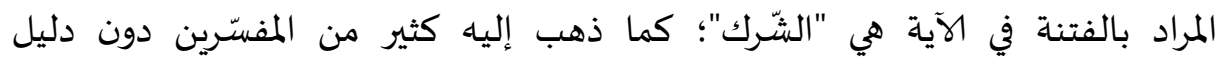


واضح، واستحلّوا بذلك قتال كلّ كافر على وجه الأرض، وإن كان مسالمًا؛ بل على أنّ المراد

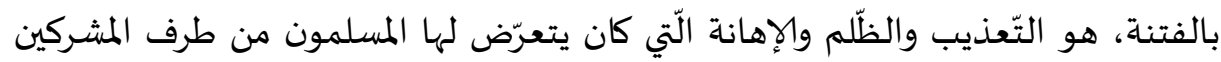

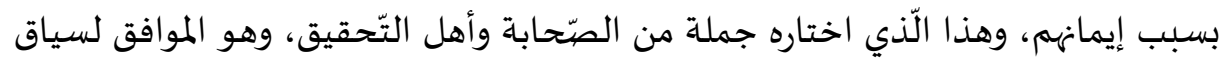
الآيات:

• عن نافع "أن رجلاً أتى ابن عمر فقال: با أبا عبد الرحمن ما حملك على أن تحجّ عاماً.

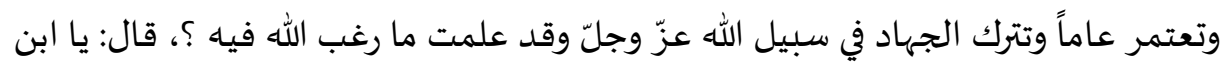

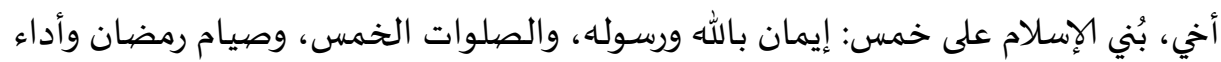

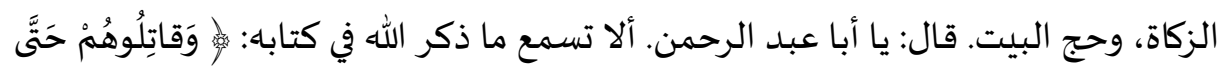

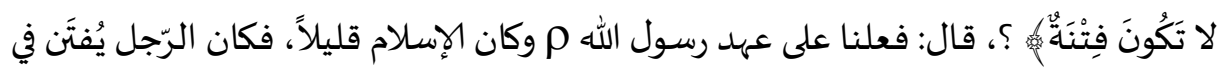

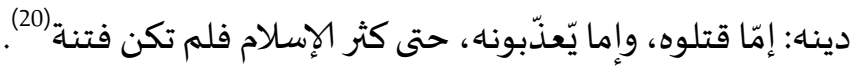

ـ وقال عروة بن الزبير: كان المؤمنون في مبدأ الدعوة يُفتنون عن دين الله، فافتتن من

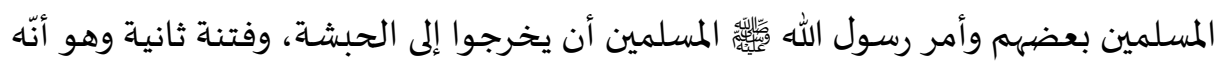

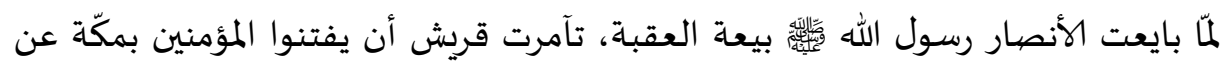

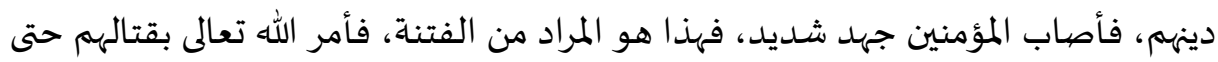

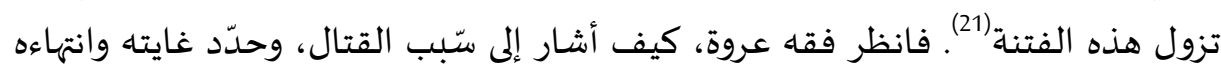
بزوال الفتنة. وهذا في الحقيقة نصٌّ عظيم في بابه يُغني عن كثير من الكلام والتّفسيرات التّتي

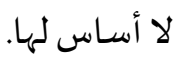

ـ قال مجاهد: لا يقاتل إلا من قاتل (22).

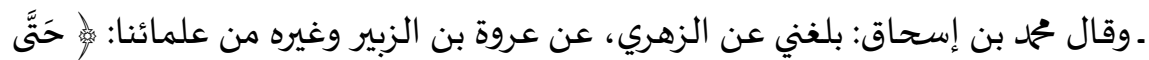

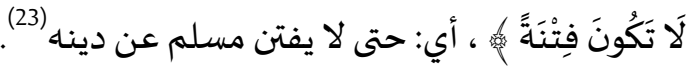

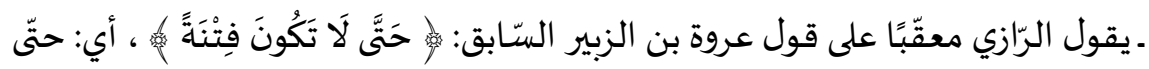

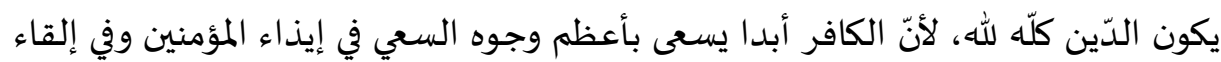

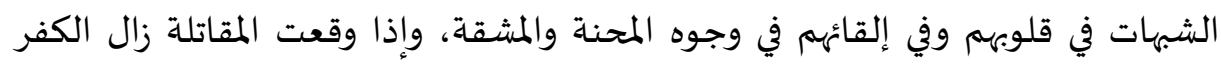

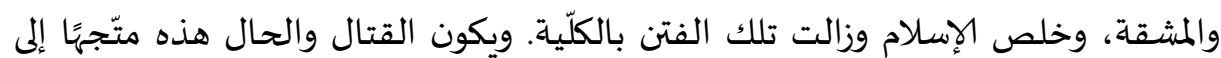
المشركين في مكّة وما حواليها، ولا يمكن حمله على جميع البلاد (24). 
ـويقول جمال الدّين القاسمي جامعًا بين الآية والحديث، ومبيّنًا صففة الّذين أُمر النّبي.

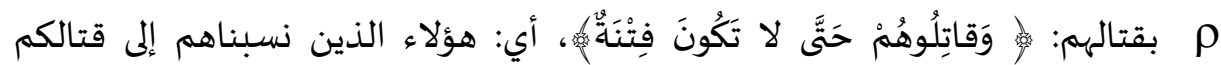

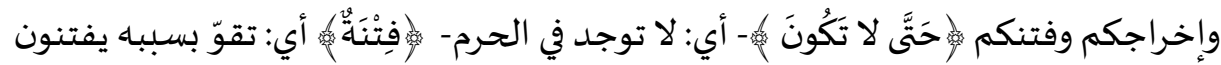

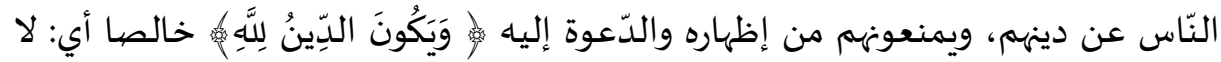

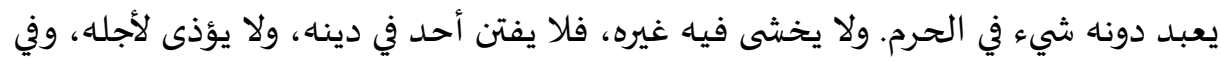

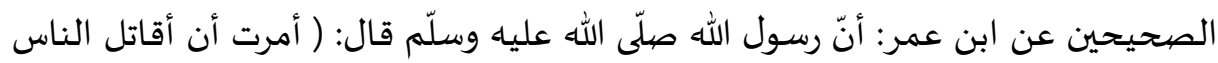

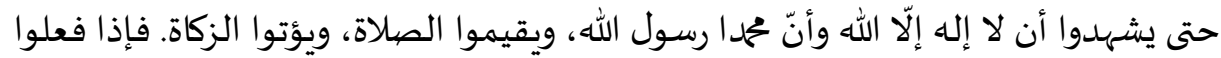

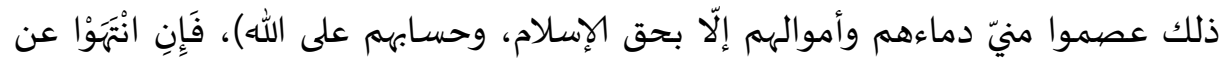

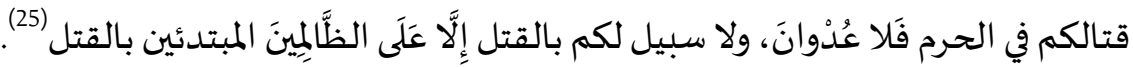
بهذه القراءة التّفسيرية التّزامنية يتبيّن مراد النّبي صلّى الله عليه وسلّم بهذا الحديث

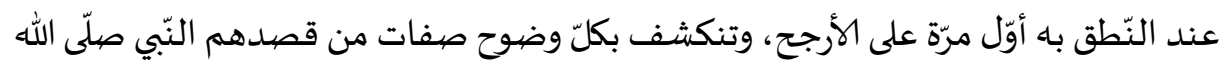

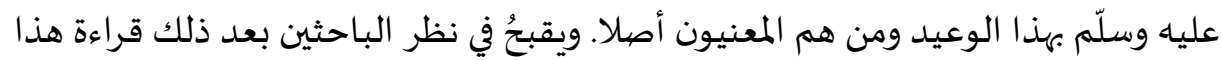

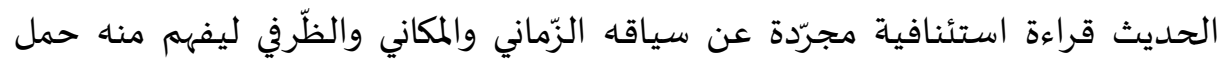

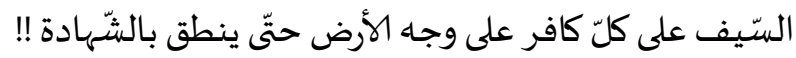

على أنّه بقي في النّفس إشكال، يجب من أجله إعادة قراءة الحديث مرّة أخرى للإجابة

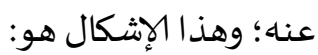

إذا كان الدّافع في إعلان النّبي م القتال على المشركين هو ابتداؤهم أوّلا قتال وإذاية

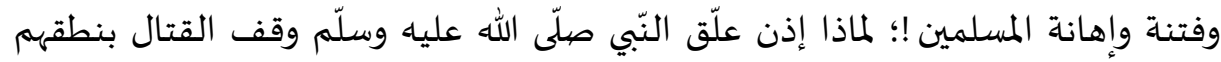
الشّهادة، وبالصّّلاة والزّكاة في روايات أخرى، أي على العموم بدخولهم إلى الإسلام ؟ لماذا لم يجعل النبّي صلّى الله عليه وسلّمم الغاية التّي ينتهي إليها القتال هي توقّفهم عن

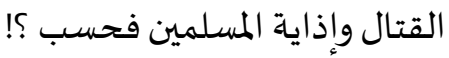
بقراءة تفسيرية أخرى لهذا النّص الحديثي في سياقه الزّماني، يتّضح الجواب على هذا الإشكال عبر نقطتين اثنتين: 
1 ـ أوّلا نطق الشّهادة أو الدّخول في الإسلام، ليس هو غاية قتال المشركين، بل هي غاية

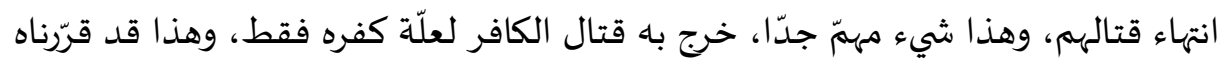
سابقًا.

2 ـ الّذين أُمِر النّبي صلّى الله عليه وسلّم بقتالهم هم المشركون الّذين قتلوا من المسلمين

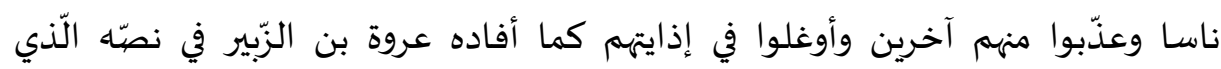

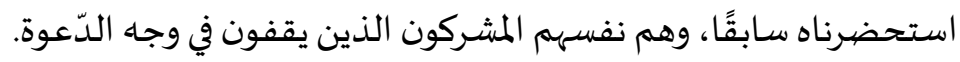
وبالتّالي دم المسلمين الّذين أوذوا واستشهدوا، وحقّهم، هو حقّ لله تعالى وجب الأخذ

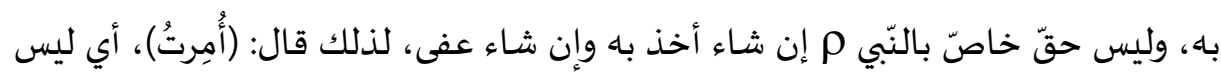

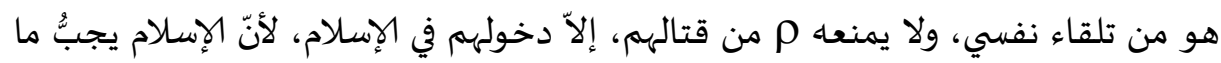
قبله.

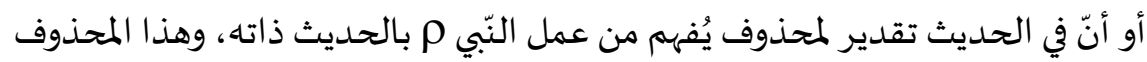

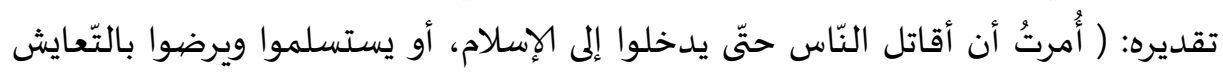

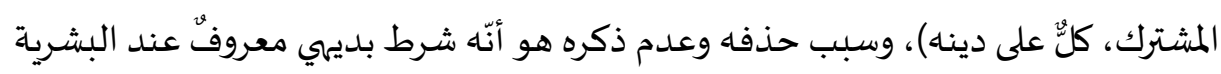

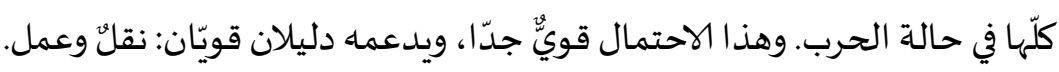
فأمّا النّقل، فما أخرجه ابن أبي شيبة في مصنّفه عن أبي هريرة قال: قال عمر: إنّ

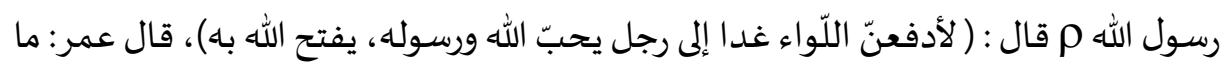

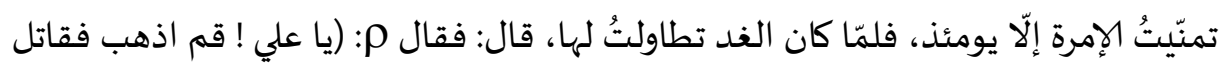

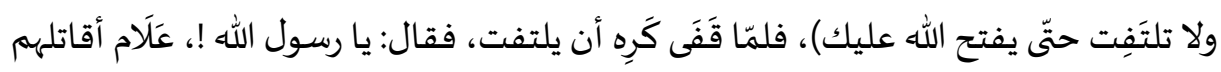

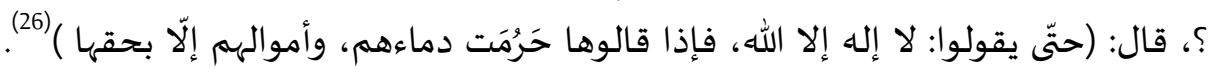
وهذا الحديث قاله النبّي م في غزوة خيبر، كما هو مُتِفق عليه. تجدر الإشـارة أوّلا إلى أنّه هناك من جعل هذه الحادثة سببا لورود أصل الحديث كما

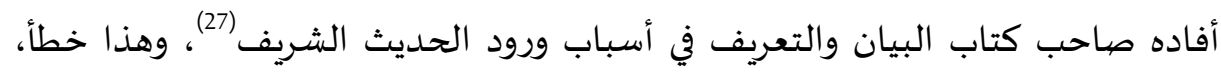

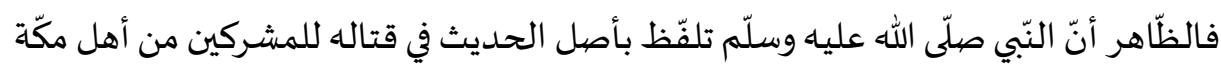

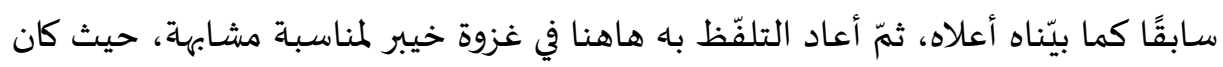


لخيبر وعلى رأسها زعماء بني النّضير دور كبير في حشد قريش والأعراب لقتال المسلمين

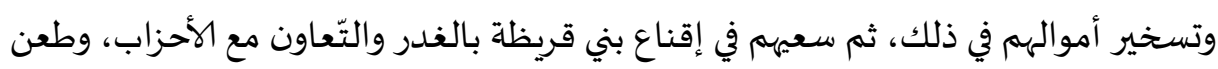

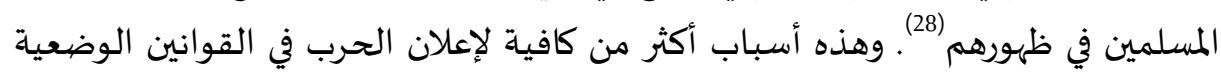
الحالية.

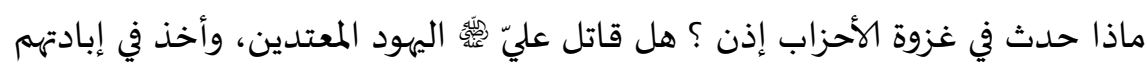

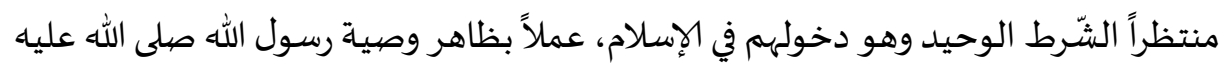
وسلّم ؟ منظخ

كلاً طبعًا، بل قاتل من استمرّ في القتال، وصالح الّذّين استسلموا على ما اقتضيته

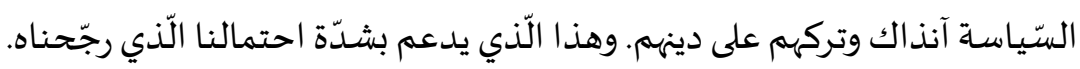

وأمّا العمل، فإنّه كما يقول ابن تيمية من تأمّل سيرة النّبي م تبين له أنه لم يكره أحدا

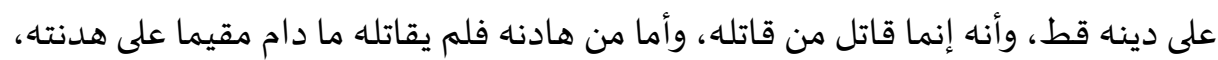

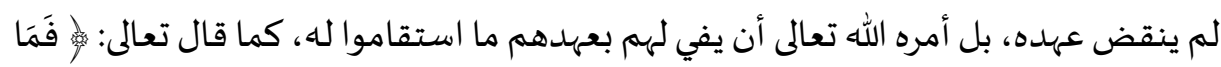

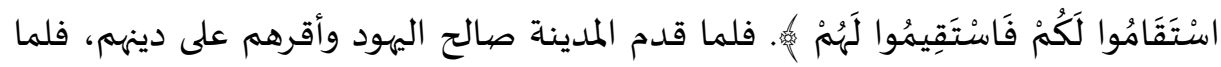

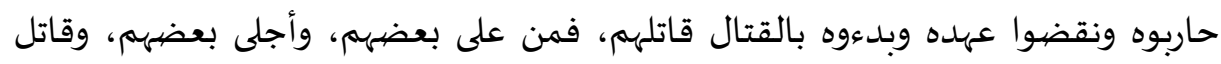

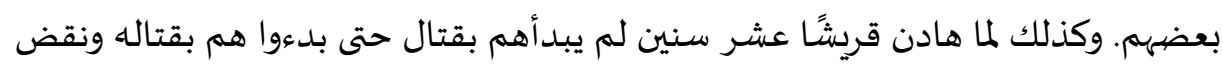

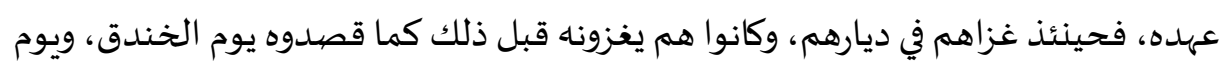

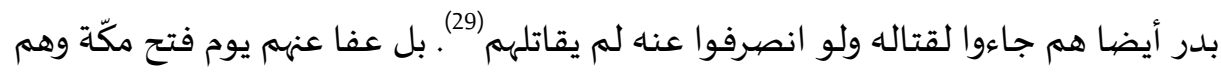

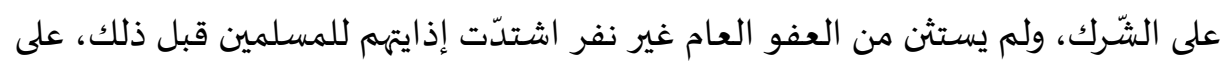
حسب ما تقتضيه قوانين العقوبة والجزاء.

وأخيرا بقي أن نشير إلى أنّ استدلال بعضهم بهذا الحديث على قتل تارك الصّّلاة،

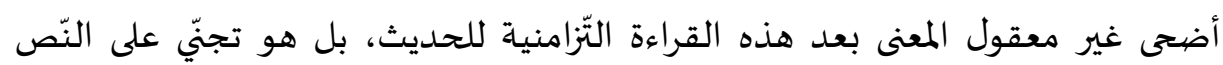

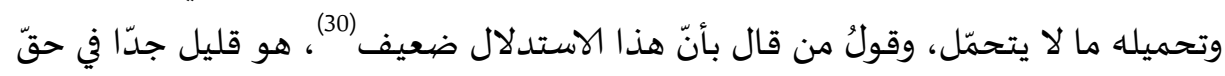
هذا التّجاوز..!!

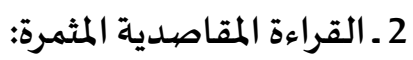


بعد قراءة هذا النّص قراءة تفسيرية تزامنية، واتِضاح صفة من قصدهم النّبي مالتِ

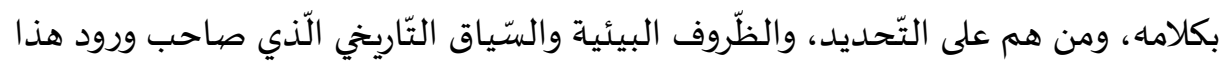

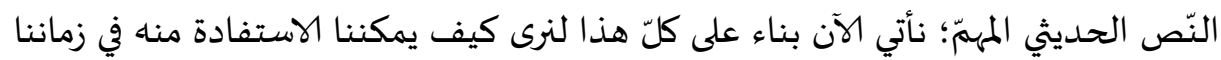
الحاضر:

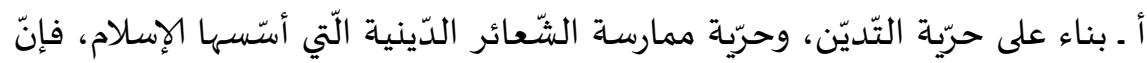

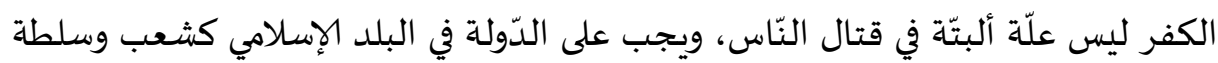

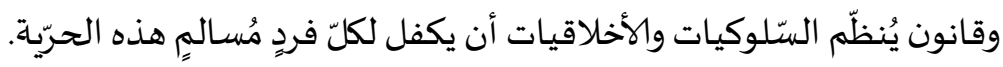

ب ـ من الواجب شرعا على المسلم أن يردّ العدوان والظّلم عن نفسهاه، وأن لا يرضى بالدّنية والهوان.

ج ـ الحاكم الأعلى للبلاد هو المخوّل له إعلان الحرب، أو إيقافها وفق الدّواعي الرّاهنة،

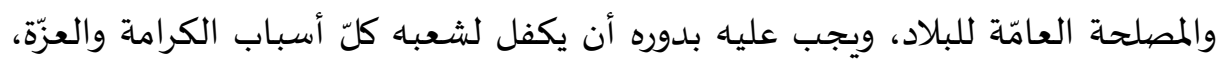
والعيش الهنيء بين باقي الأمم.

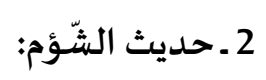

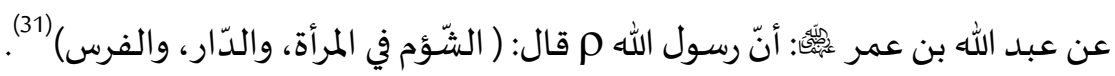
هذا الحديث أخذ حيّزًا كبيرا من اهتمام المسلمين والباحثين على الخصيوص، وشكّل

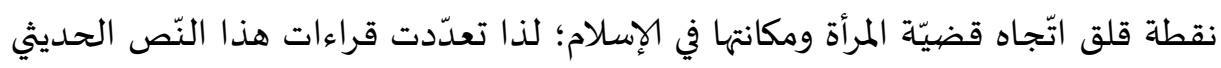

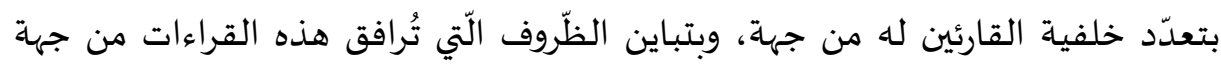

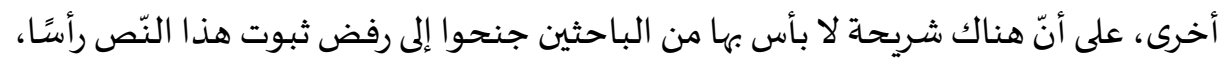

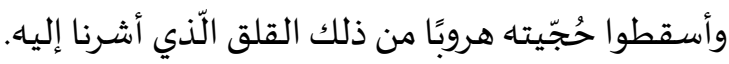

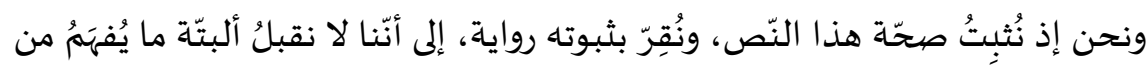

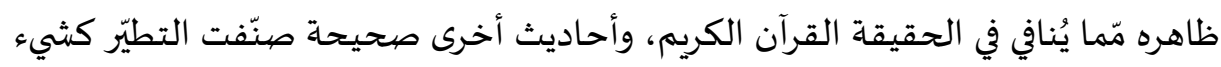

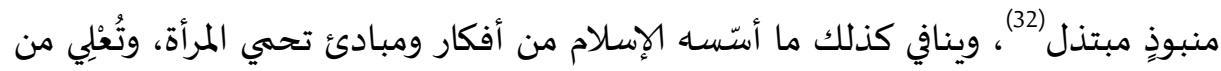

مكانتها الاجتماعية ! منود مبتذب 
لذا وجب الرّجوع إلى المكان والزّمان والمحيط الّذي صاحب صدور هذا اللّفظ من فم

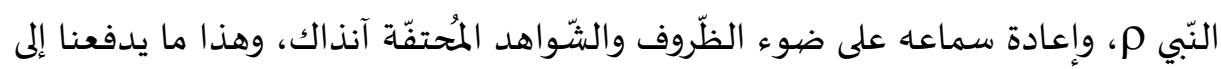
إعادة قراءة هذا النّص الحديثي المهمّ وفق المنهج الّذي أسّّنساه سابقًا:

\section{أ ـ القراءة التّفسيرية التّزامنية لهذا النّص:}

تجدر الإشـارة إلى أنّ جميع روايات هذا الحديث، ترجع في عُمُوم معناها إلى أربع روايات،

1 ـ رواية تُفيد الإثبات على اختلاف ألفاظها: ( إنّما الشّؤم في ثلاثة، في الفرس والمرأة

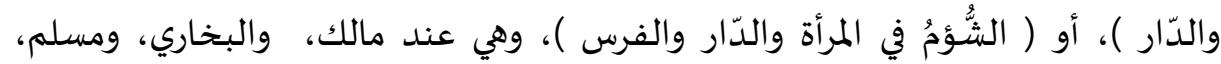

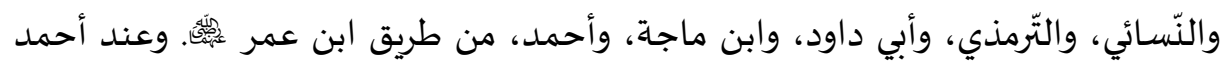

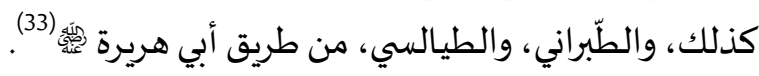

2 ـ روايةٌ تُفيد النّفي المُستفاد من تعليق أثر الشّؤم، على اختلاف ألفاظها: ( إن كان

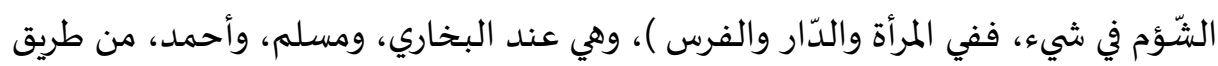

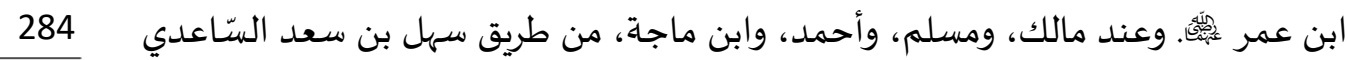

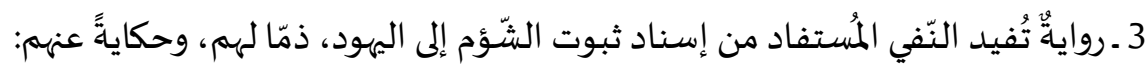

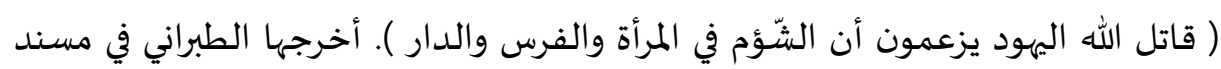

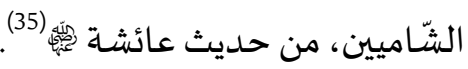

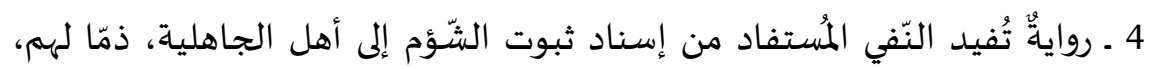

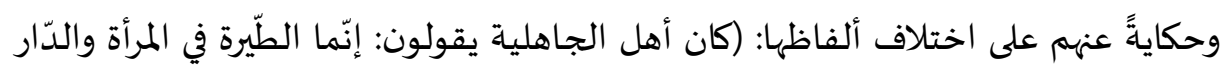

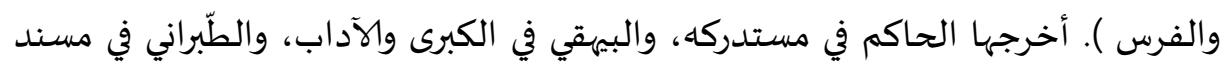

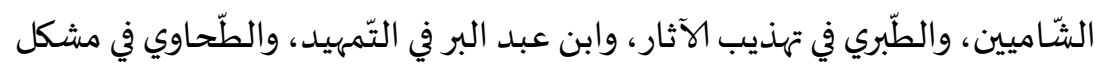

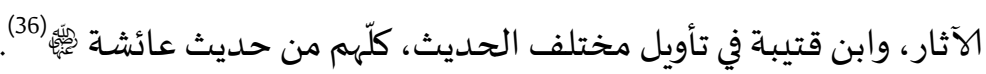
نأتي الآن إلى تصوير الظّرف الزّماني والمكاني الّذي نطق فيه النّبي م بهذا النّص الحديثي: 


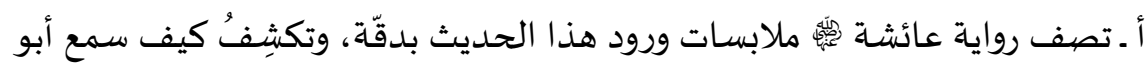

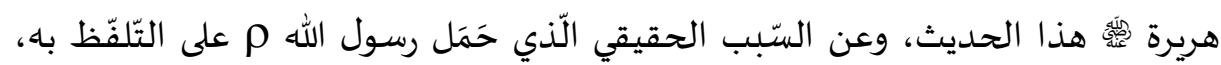

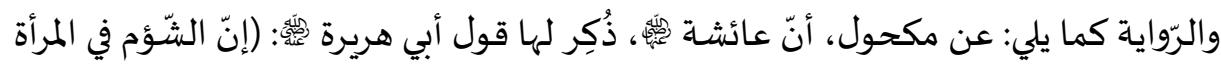

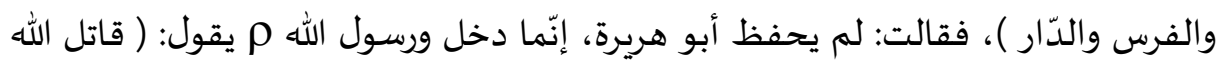

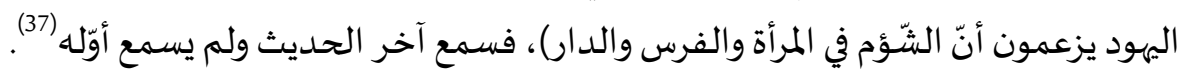

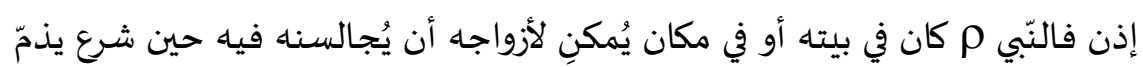

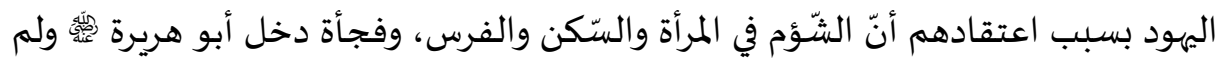
يكن قد حضر أوّل المجلس، فلم يسمع قول النّبي م: ( قاتل الله اليهود) ولَحِقِق بقوله: ( الشّّؤم

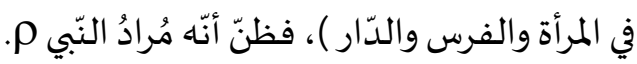
ب ـ الظّاهر أنّ هذه الاعتقاد كان شائعًا آنذاك في المجتمع الجاهلي مثلما كان شائعا

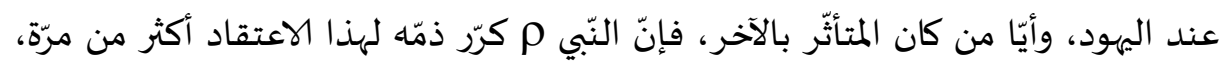

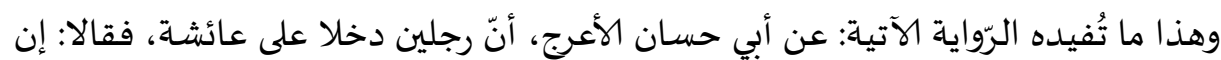

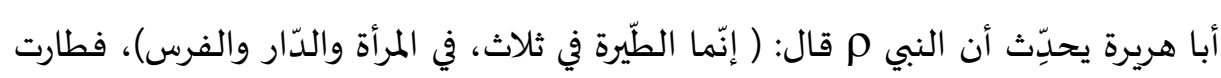

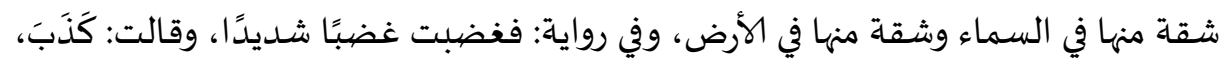
والّّني أنزل القرآن على قلب محمد م ما حدّث بهذا، ولكن رسول الله م كان يقول: ( كان أهل

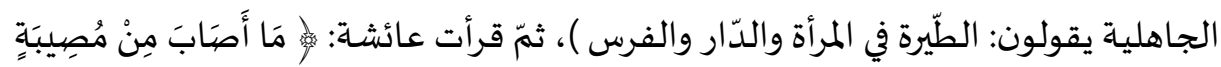

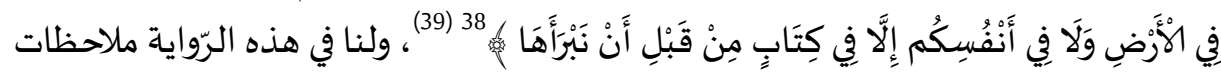

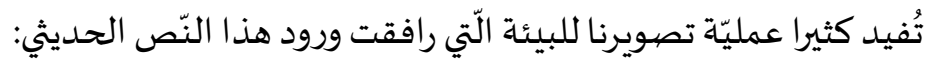

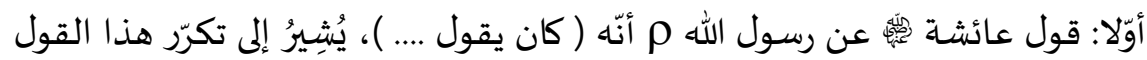

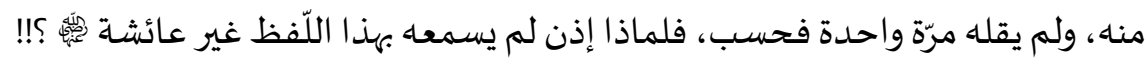
والجواب: أنّه من المُحتمل جدّا أنّ هذا القول تكرّر من النبّي م في حضرة عائشة رضي

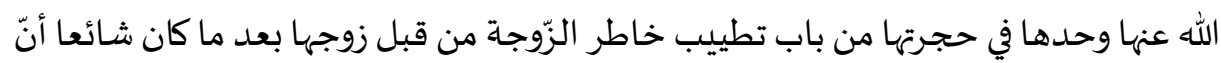

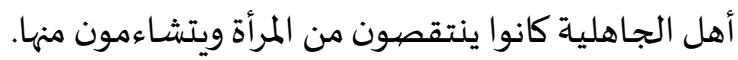


ثانيا: لم تكن حكاية عائشة لقول النبّي م في هذه الرّواية من باب تسجيلٍ لحديث

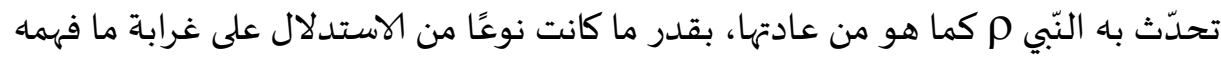

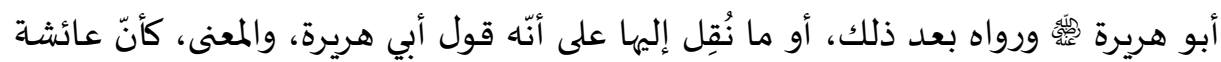

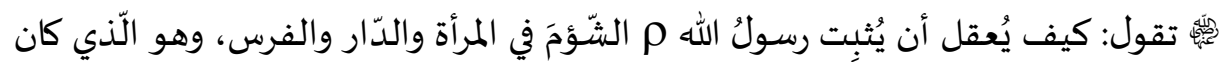

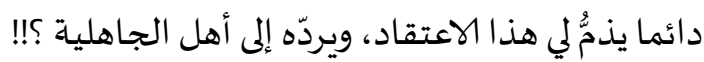

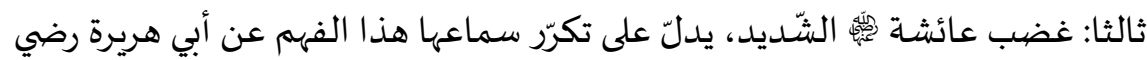

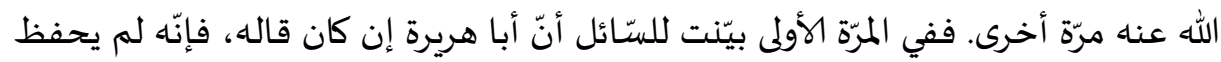

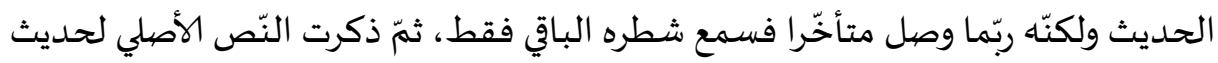

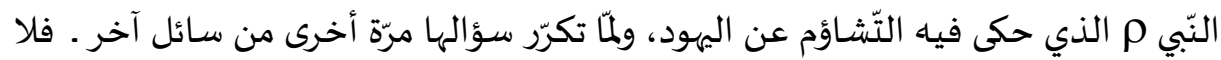

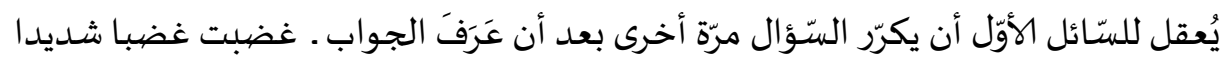

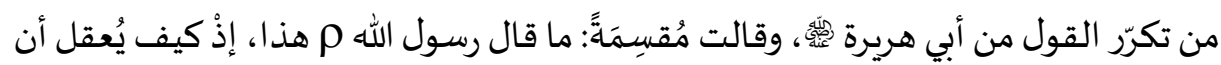

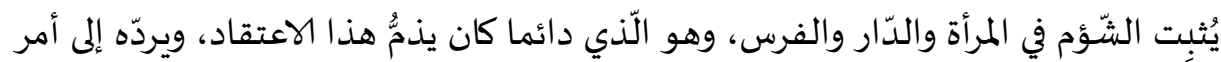

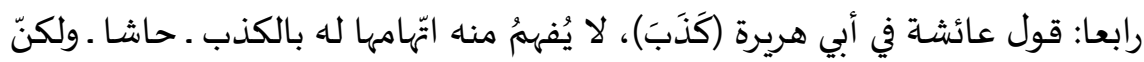

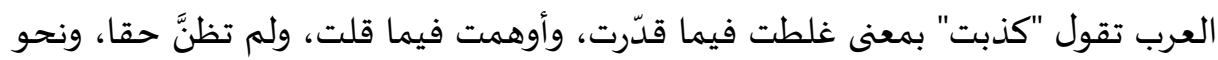

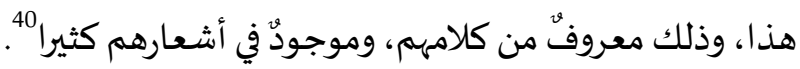
ب ـ رواية الإثبات على اختلاف ألفاظها لم يروِها غير أبي هريرة وابن عمر رضي الله عنهم:

فأمّّا أبو هريرة، فقد تقدّم توهّمها في المسألة، ويُحتَمَلُ كذلك أن يكون ناقلًا وهِمِ عن أبي

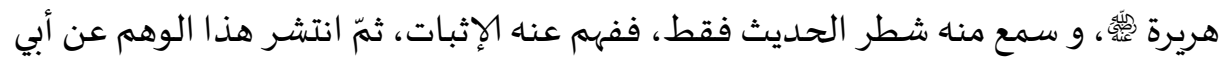

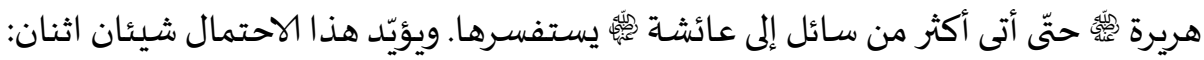

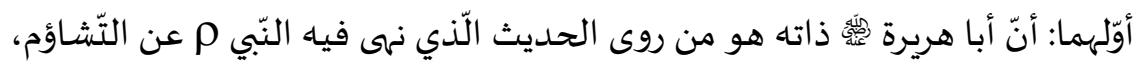

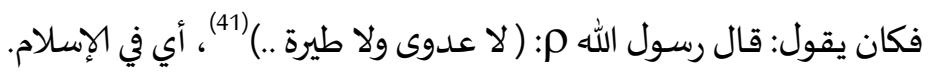
ثانيهما: نَفْيُ أبو هريرة ما نُسِب إليه من إثبات التّشَاؤم في المرأة و الدّار والفرس، فقد

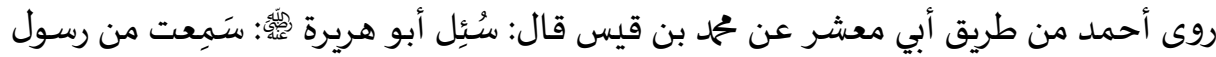


الله م: ( الطّيرة في ثلاث في المسكن والفرس والمرأة )؟، قال: كنتُ إذن أقول على رسول الله م ما لم يَقُل، ولكن سمعتُ رسول الله م يقول: (أصدق الطّيرة الفأل والعين حقّ ) (422. وأمّا رواية ابن عمر، فلنا فيها احتمالان كذلك:

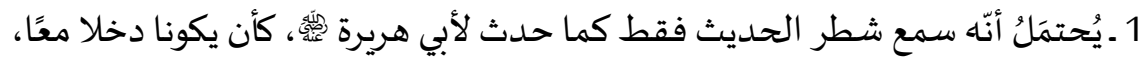
أو سمعاه في مناسبة أخرى كذلك.

2 ـ أن يكون الشّطر الأوّل قد سقط سهوا من بعض الرّواة عن ابن عمر، أو نتيجة

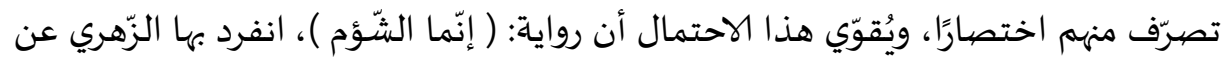

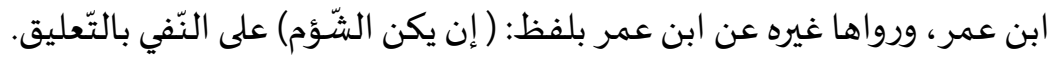
والأمر الخطير، والّذي يدلّ على دقّة فهم الألباني رحمه الله أنّه علّق على حديث

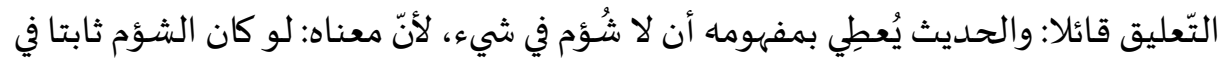

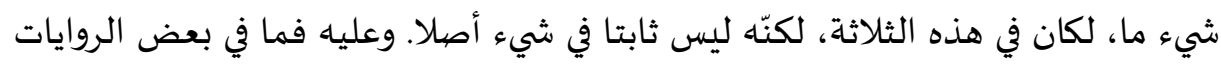

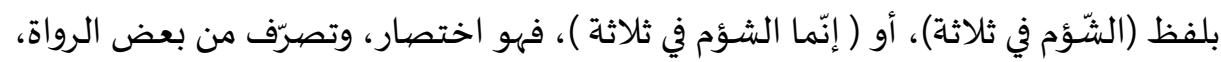
والله أعله (43).

وعليه، فإنّ اللّفظ الصّحيح الّذي خرج من فم النّبي م بخصوص الشّؤم، في ذلك

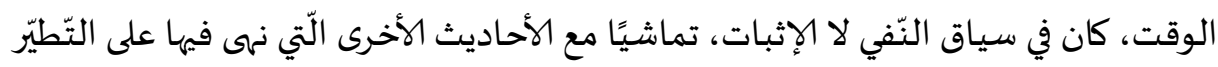

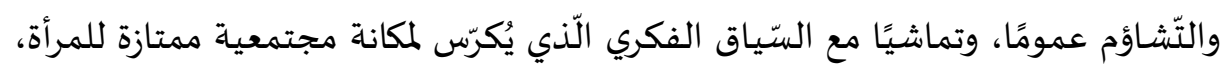

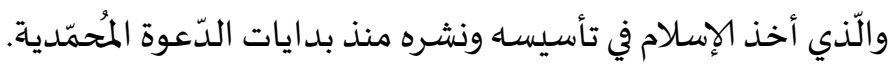

\section{ب ـ القراءة المقاصدية الإسقاطية:}

من العجيب أن يُدافع بعض أهل العلم (44)، على أساس صحّة الرّواية وثبوتها، عن

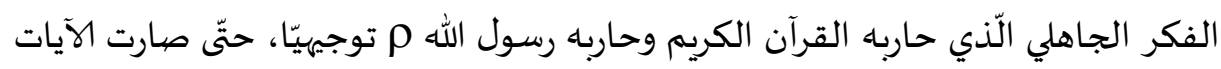

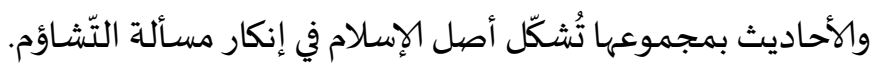

وإن كان هناك ما يُستفاد من هذا النّص الحديثي، فهو على الأرجح في سياق معاكسٍ

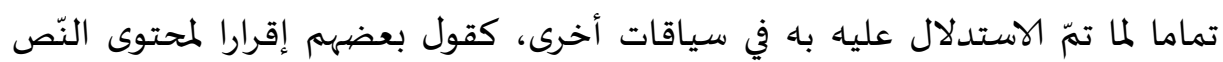

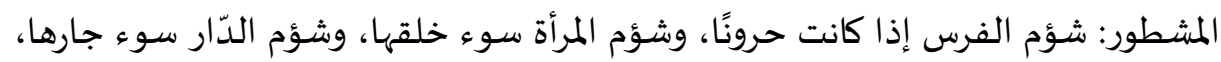


وقيل: شؤم الفرس أن لا يغزى عليها، وشؤم المرأة أن لا تلد، وشؤم الدّار ضيقها. وقيل: شؤم

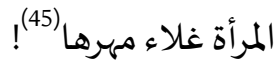

فهذا كلامُّ لا نقبله أبدا، لأنّ النبّي م ما أراده وما قصيده، وما تلفّظ بما يُفيده أسـاسًا،

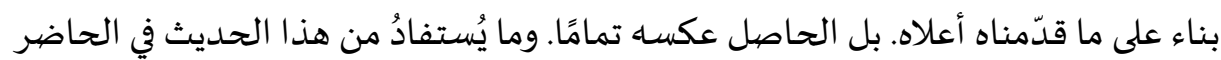

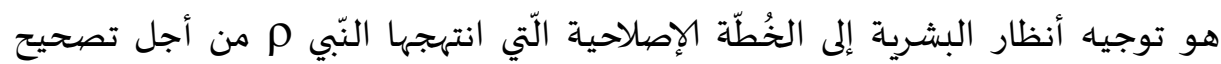

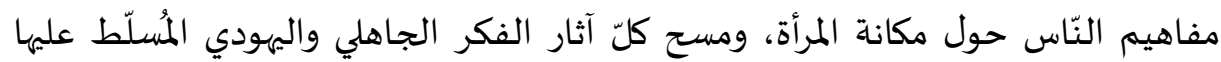

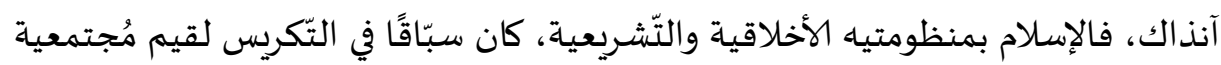

$$
\text { 3اقية تضمن للمرأة حياة كريمة. }
$$

قال رسول الله م: ( من بدّل دينه فاقتلوه ) (46).

بقراءة سطحية لهذا النّص الحديثي، نَصْدُرُ عن ملمِ غامض حول منهج الإسلام في

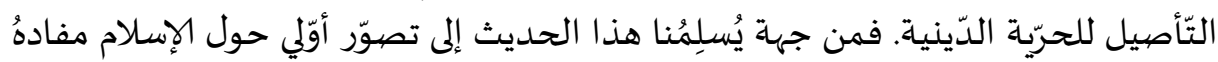

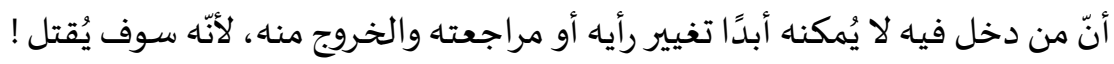
ومن جها أخرى نجد روح القرآن الكريم تؤسّس لحرّية الاعتقاد، وآياته تتحدّث عن

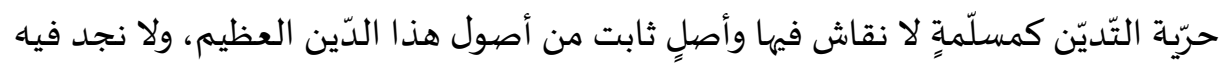

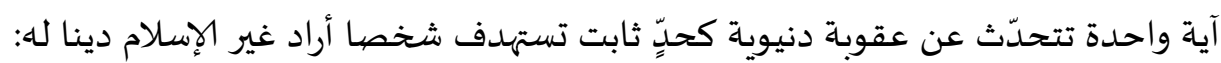

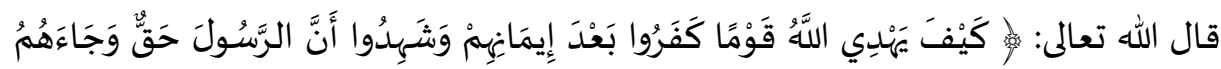

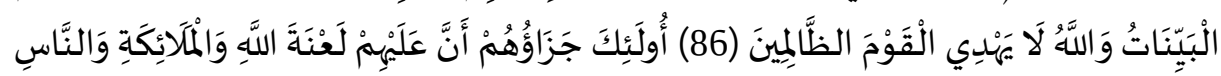

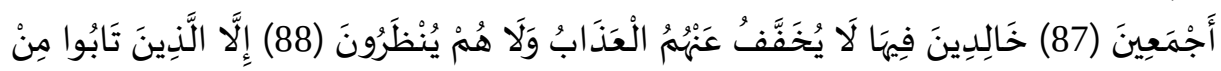

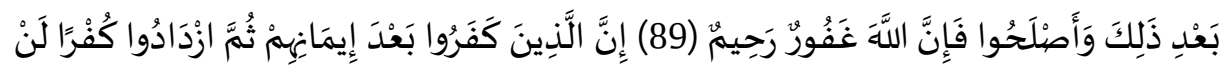

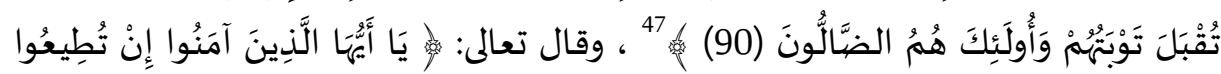

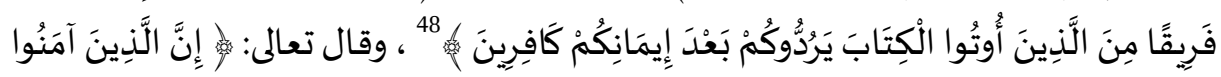

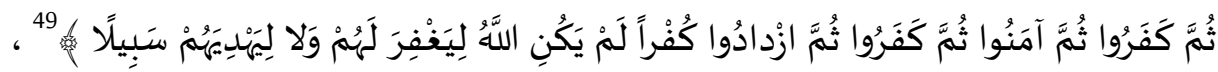

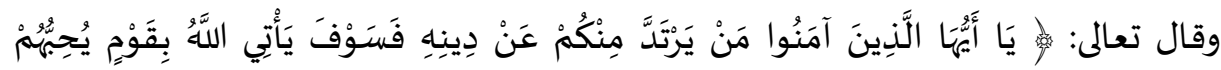

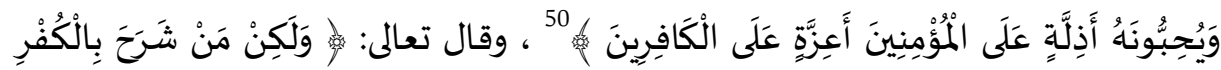

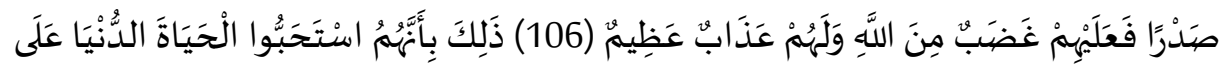




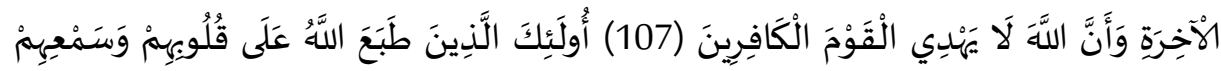

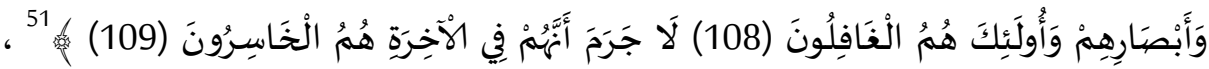

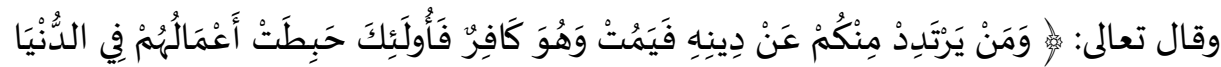

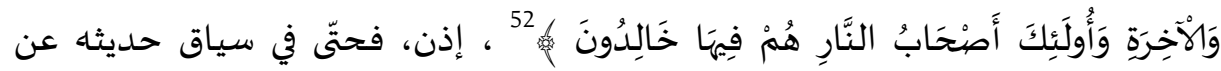

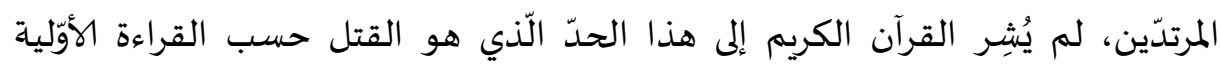

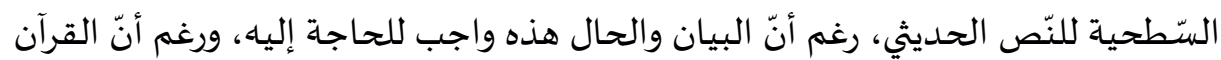

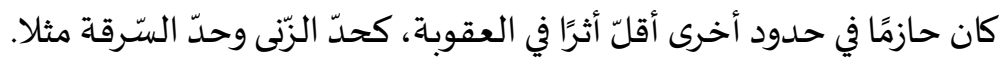
هذا الملمح الأوّلي الغامض، يدفعنا إلى طرح جملة من الإشكالات، ينبغي الوقوف عليها، والتّفكير فيها:

\section{1. لماذا لم يُشِر القرآن إلى عقوبة دنيوية للمرتدّ عن الإسلام ؟}

2 ـ هل هناك تصوّر آخر للفظ المرتدّ الذّي ورد في النّص الحديثي، وهل يوجد فرق بين اللّفظ القرآني واللّفظ الحديثي من جانب المفهوم ؟

3 ـ أيّ انسان يمرّ بمراحل التّناسخ الفكري، ومراجعة أفكاره وقناعاته، بتأثير من حجم وقيم

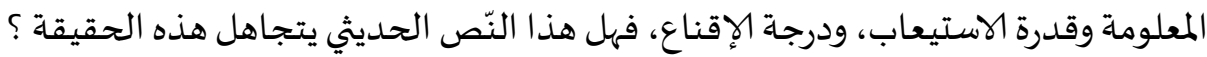
وللإجابة على هذه التّساؤلات وتساؤلات أخرى، نعمدُ الآن إلى قراءة هذا الحديث قراءة

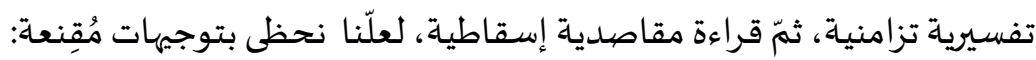

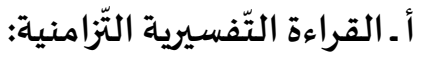

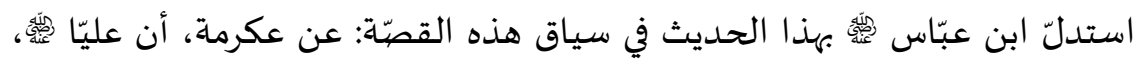

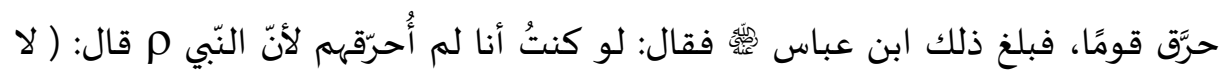

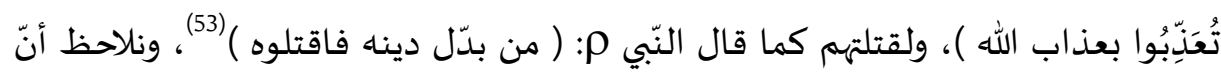

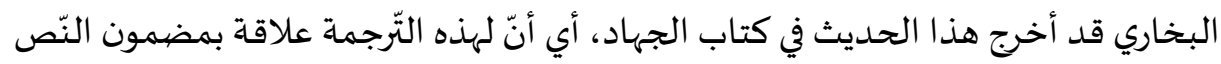

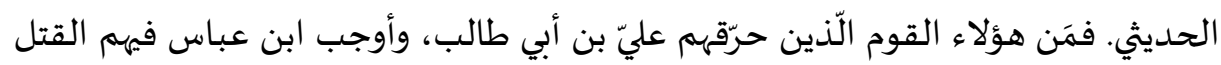

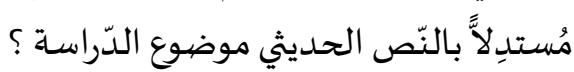


في روايات أخرى تنكشفُ أوصافق أخرى مؤثّرة لهؤلاء القوم، فهم المرتدّون، وهم

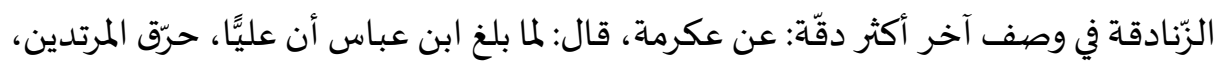

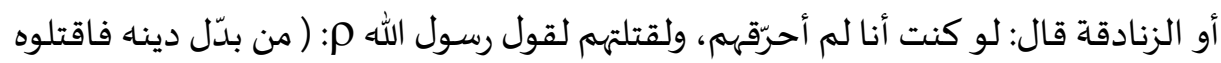

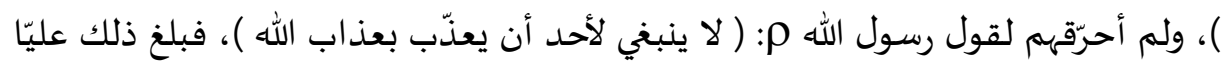

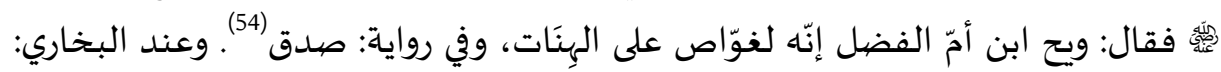

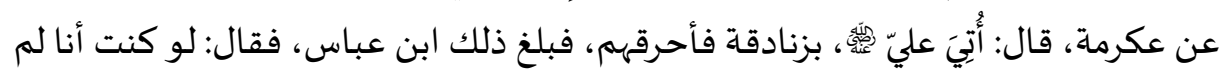

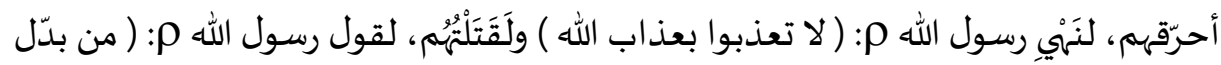
دينه فاقتلوه (55).

فمَن هم الزّنادقة إذن، وهل يجوز قتلهم لأجل زندقتهم ؟

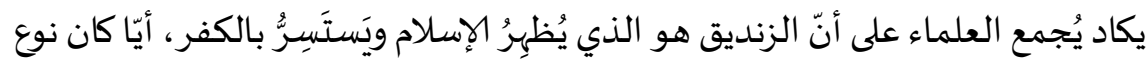

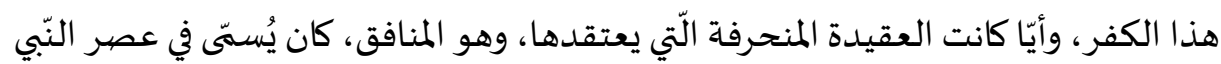

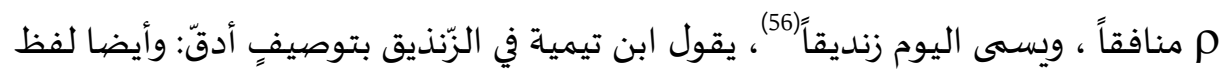
الزّندقة لا يوجد في كلام النبي م كما لا يوجد في القرآن، وهو لفظ لفئ أعجميّ معرّب من كلام

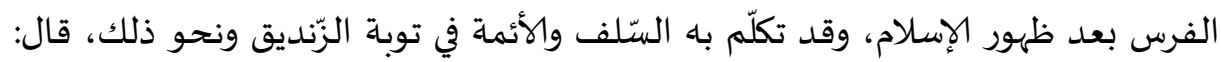

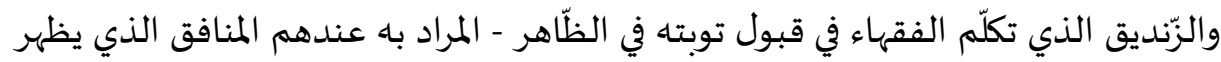

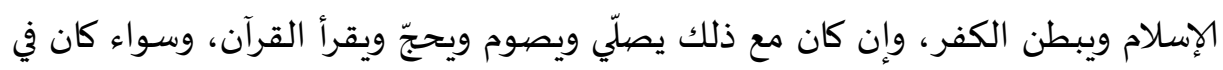

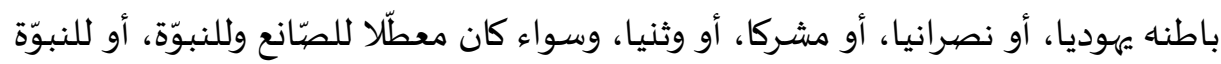

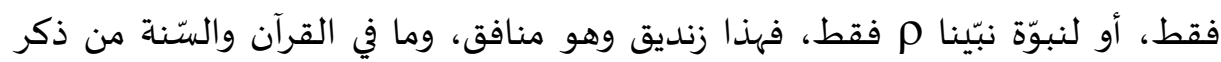

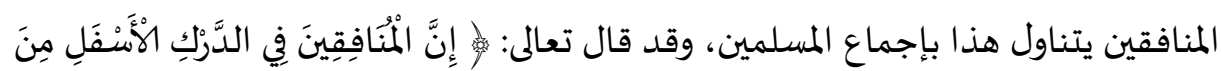

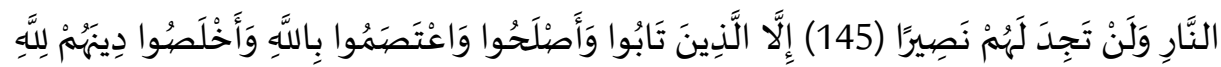

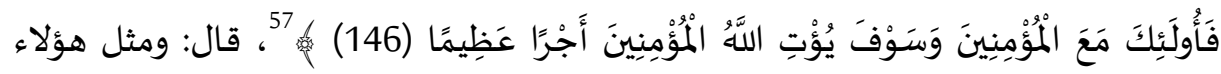

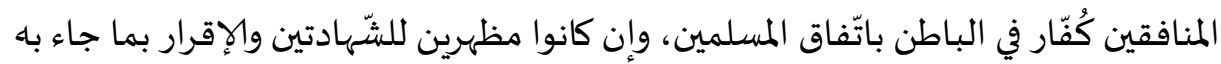

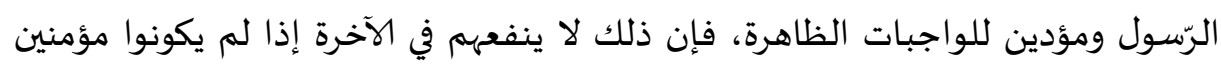
بقلوبهم باتفاق المسلمين (58).

وعليه فالزّندقة نوعٌ من أنواع النّفاق إذا لم يكن هو النّفاق بعينه، وقد مضت سنّة

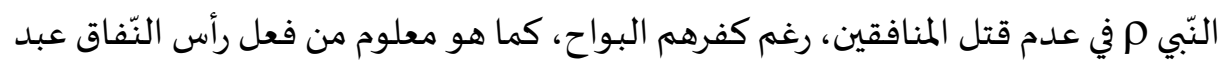




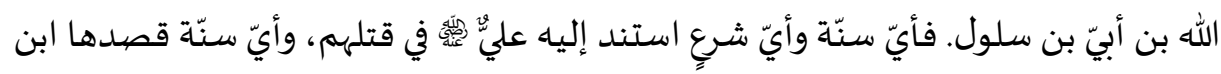

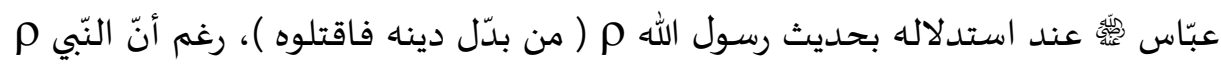

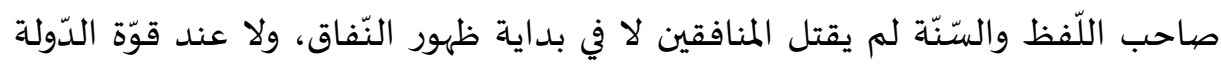
الإسلامية ومنعتها، علاوة على أنّ القرآن الكريم صرّح بكفرهم في كلّ مرّة...؟!

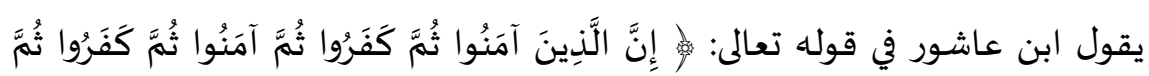

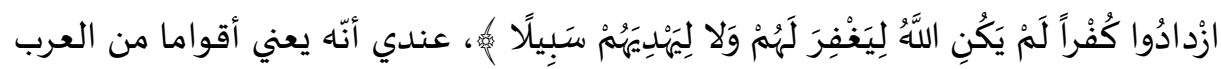

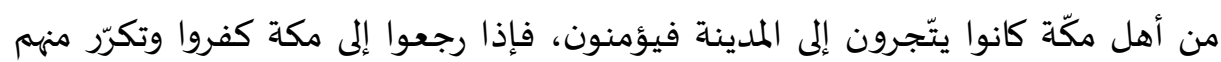
ذلك (59) وكان يعلم النّبي م ذلك منهم ولم يقتلهمه

وليس هناك ما هو أوضح من هذه الآية في عدم جواز قتل المنافق المرتدّ، وإجباره على

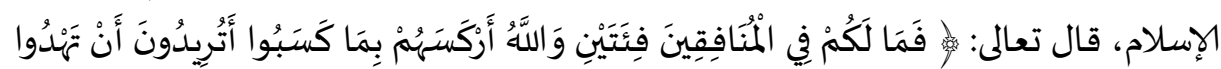

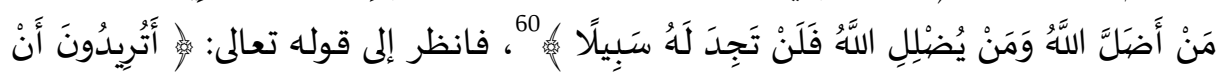

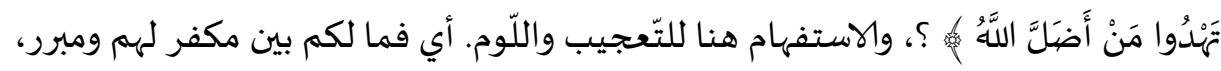

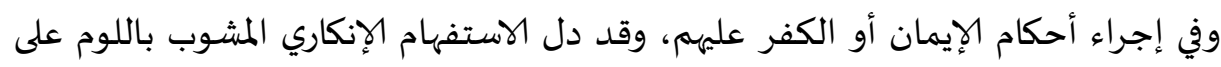
291

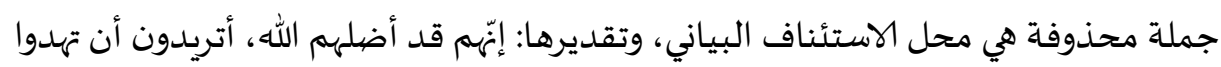

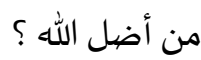

وفي المقصودين بهذه الآية أقوال:

1 ـ أنّها نزلت في المنخزلين يوم أحد: عبد الله بن أبي وأتباعه، اختلف المسلمون في

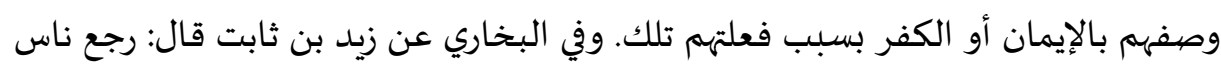

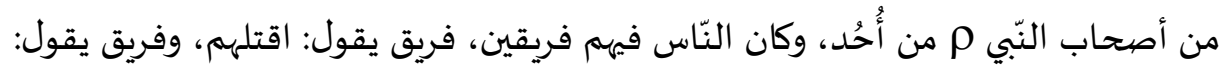

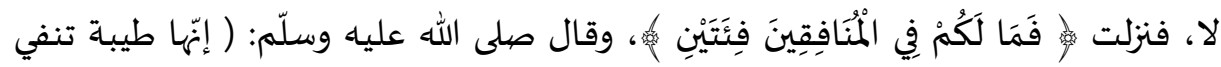

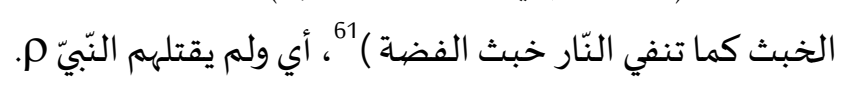

2 ـ أنّها نزلت في قوم أظهروا الإسلام بمكّة ولم يهاجروا، وكانوا يظاهرون المشركين على 
يقول ابن عاشور: وأحسب أنّ هؤلاء الفِرَق كلّهم كانوا معروفين وقت نزول الآية، فكانوا

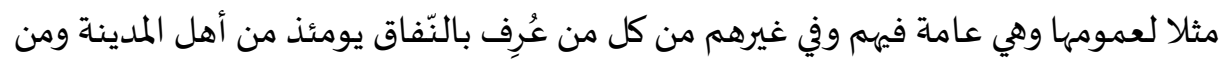
أهل مكة (62).

ولعلّنا نأخذ من هذه الروايات وسبب نزول هذه الآيات الملاحظ التّالية: أ ـ المنافقون أو الزّنادقة على وصف المتأخّرين الذّين لم ينحازوا قتالا إلى فريق

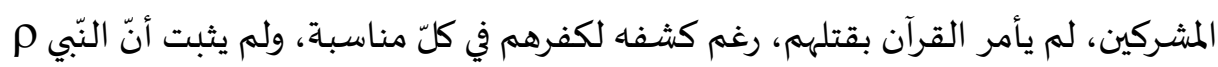

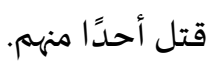

ب ـ المرتدّون الّذين لم تكن تعنيهم الحرب وأوزارها، بل كان همّههم التّجارة وأرباحها،

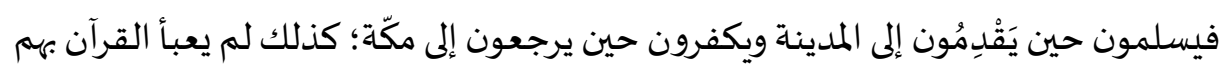
ولم يأمر بقتلهم وما فعل النبّي م ذلك.

ج ـ قول النبّي م في المنافقين بعد أن خذلوهم يوم أُحُدد: (إنّها طيبة تنفي الخبث كما

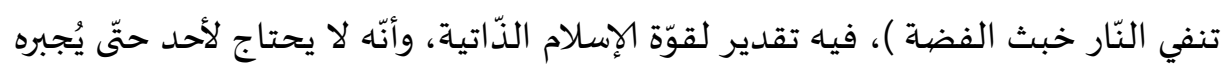

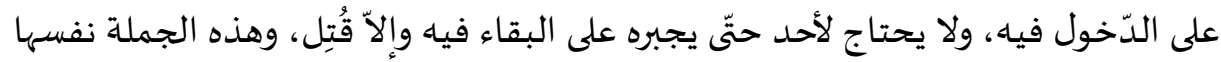

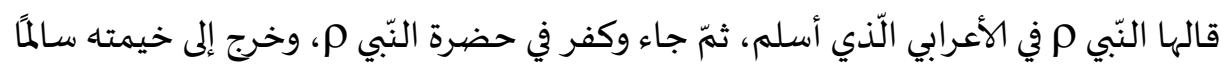

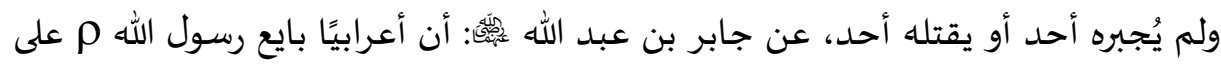

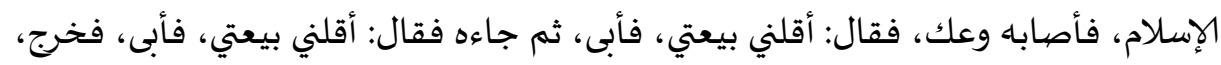

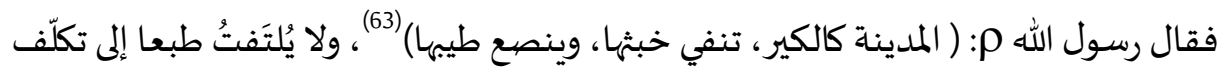

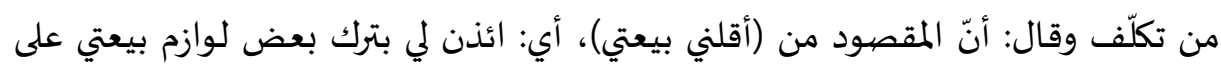

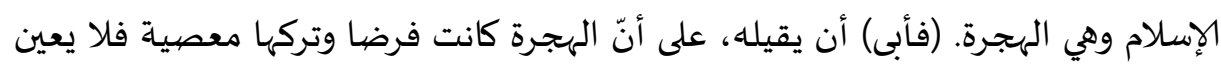

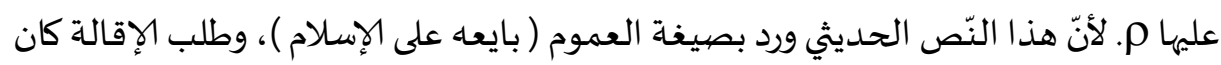

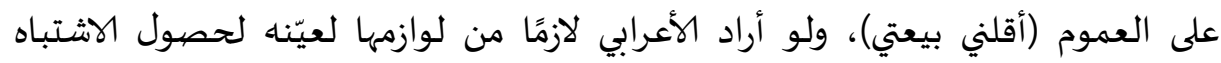

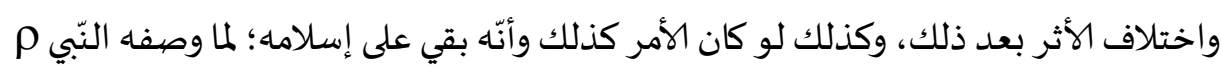

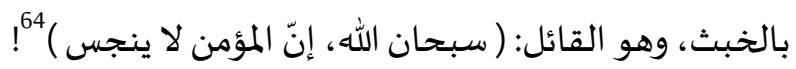
وعليه فالقراءة المنطقية لهذا الحديث تكون كالآتي: يبدو أنّ الأعرابي قدِم المدينة وبايع النبّي م على الإسلام ومن لوازم البيعة آنذاك الهجرة إلى المدينة لأسباب ليس هنا مجال 


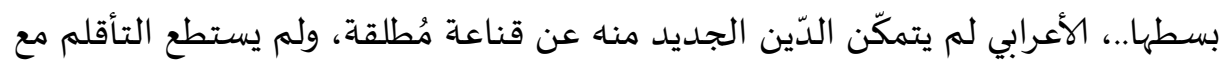

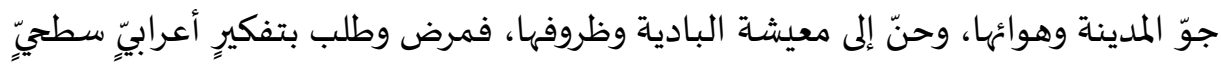

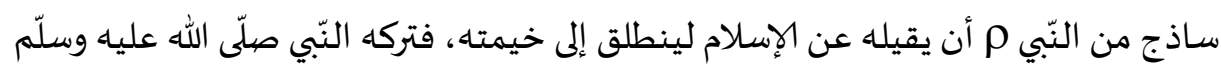

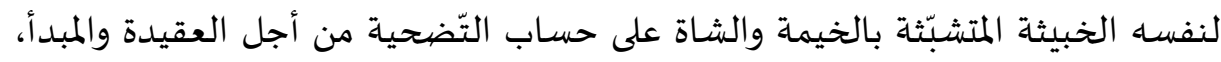

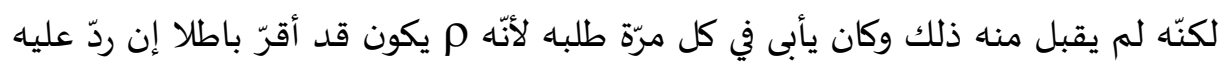
بالإيجاب.

دـ ـ على الأرجح، هناك من دخل في الإسلام في عهد النبّي م، ولم تدفعه القناعة العقلية

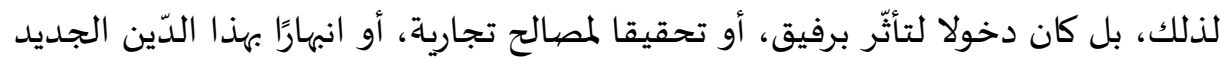

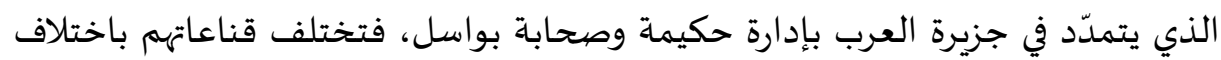

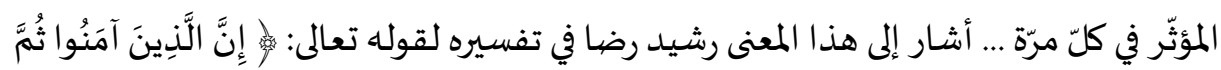

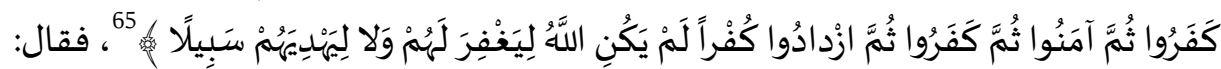

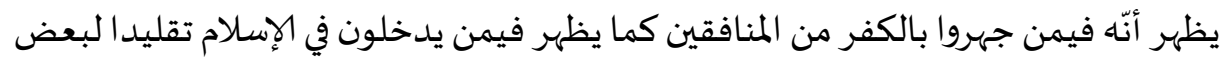

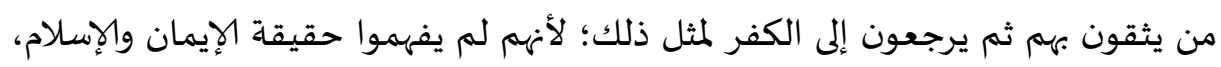

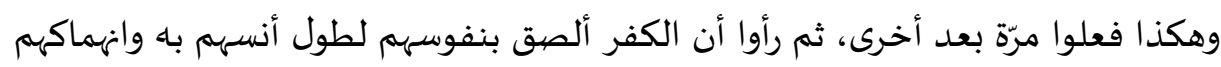

نعود الآن إلى قصة قتل عليّ بن أبي طالب للزّنادقة وتأييد ابن عبّاس له في أصل القتل

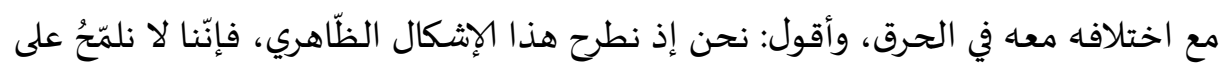

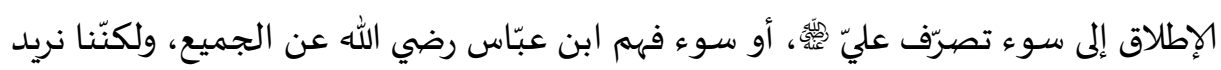

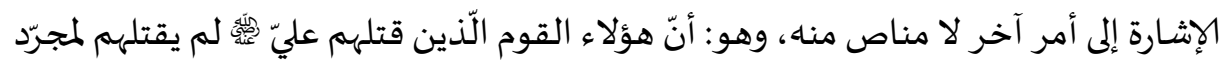

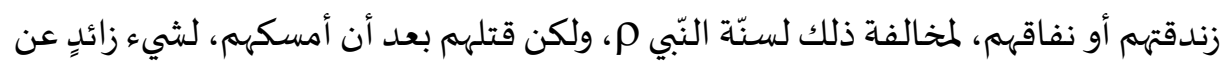

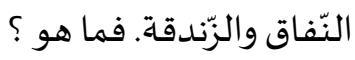

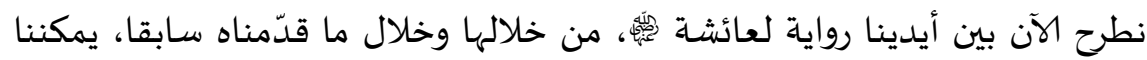

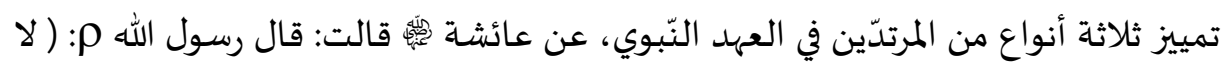

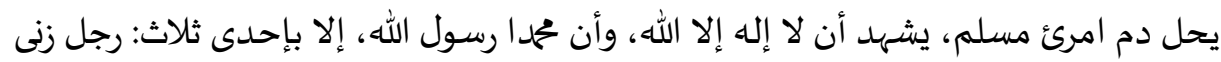

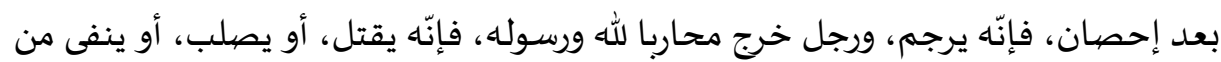


الأرض، أو يقتل نفسا، فيقتل بها)(67). وهذا الحديث يُفْهَهُ به حديث: ( لا يحلّ دم رجل

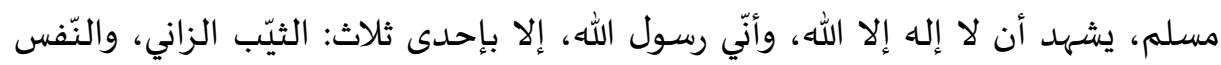

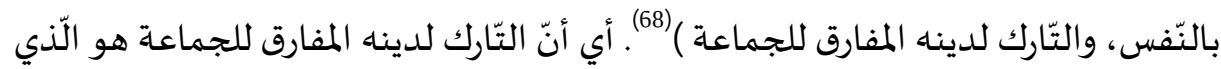
فعل ذلك ليلحق بصفوف المشركين محاربا لله ورسوله.

وعليه فإنّ المرتدّ في الوقت الّذي تلفّظ به النّبي م بهذا النّص: ( من بدّل دينه فاقتلوه )،

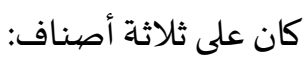

1 ـ صنف منافق بيّن النّفاق، حكم عليهم القرآن بالكفر، لا على المسلمين حملوا

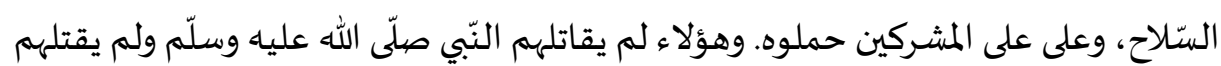

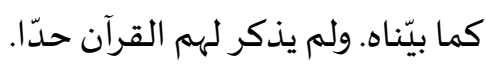

2 ـ صنف كفر بعد إيمانه كفرا واضحا وجهر به أمام النّبي م والنّاس، لكنّه ذهب في

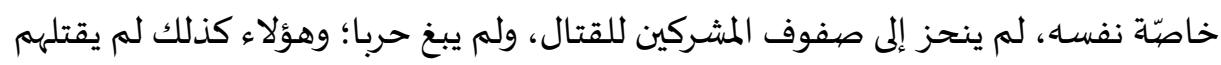
النبّي صلّى الله عليه وسلّم ولم يذكر لهم القرآن حدّا.

3 ـ صنف ارتدّوا عن الإسلام، وانحازوا إلى صفوف المشركين لمحاربة الله ورسوله 294 والمسلمين، وهؤلاء هم المقصودون إذن بقوله م ( من بدّل دينه فاقتلوه )، الوارد في سياق إنداق

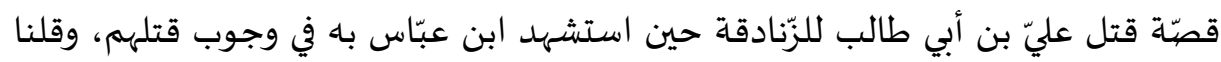

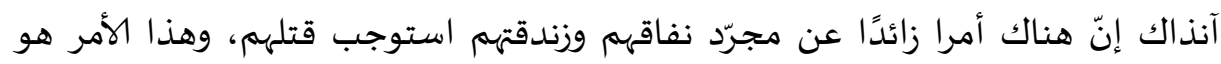
المحاربة، كما اتضّح هنا. وهذه القراءة التّزامنية تدعمها وقائع أخرى، نذكرها ليكتمل التّصوير الواقعي للظّرف

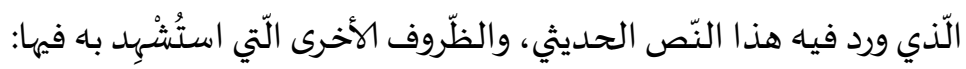
أ ـ عن عكرمة، أنّ عليّا حرّق قومًا ارتدّوا عن الإسلام، فبلغ ذلك ابن عباس، فقال: لو

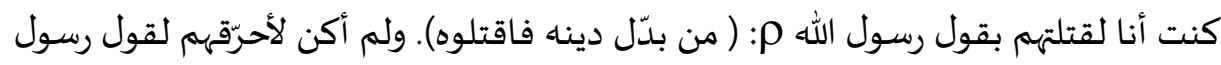

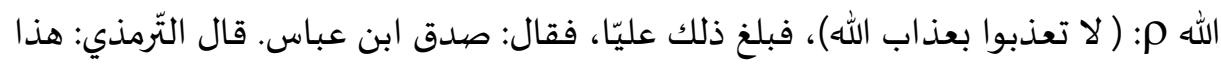

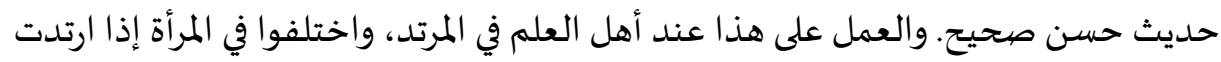

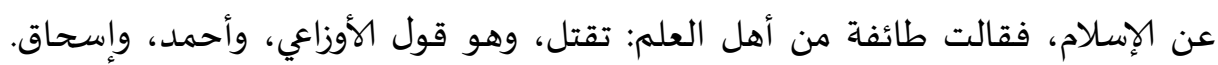

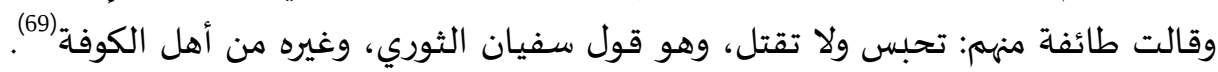


فانظر إلى تعليق التّرمذي على الحادثة؛ قال: واختلفوا في المرأة إذا ارتدّت عن الإسلام بين

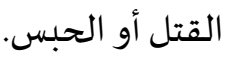

\section{فلماذا السّّن إذا كانت لا تُقتل ؟}

والجواب: أنّها محاربة، فإذا لم تقتل وأطلق سراحها فستعود إلى قتال المسلمين،

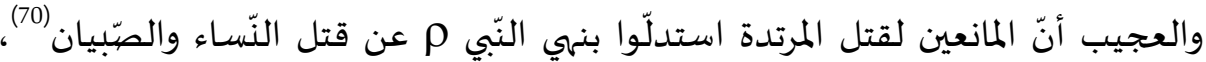

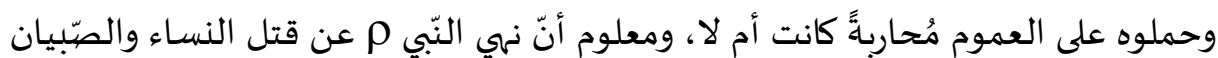

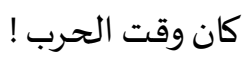

ب ـ الوضع القائم الّذي كان بين المسلمين والمشركين هو الحرب على العموم، وغالب

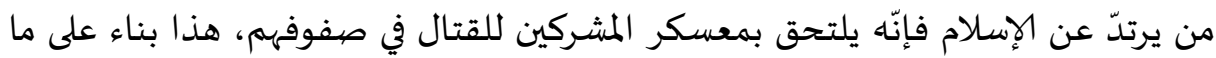

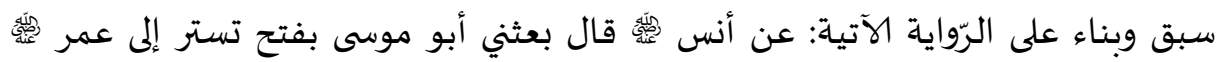

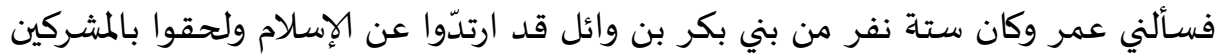

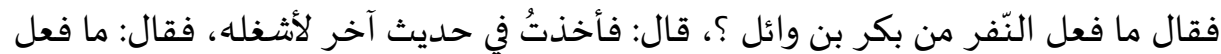

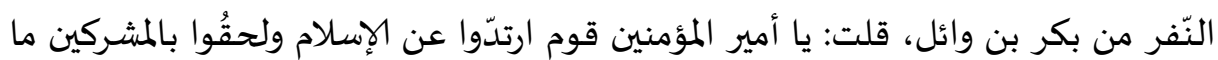

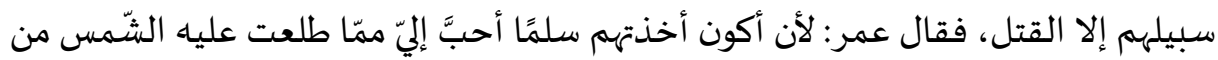

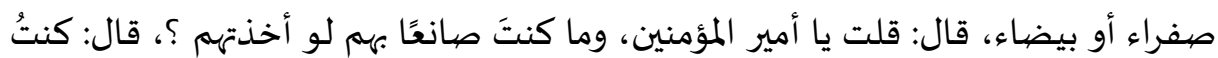

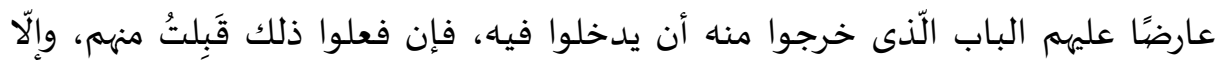
أستودعههم السّجن (71).

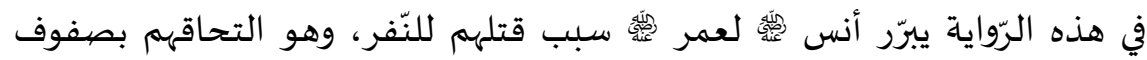

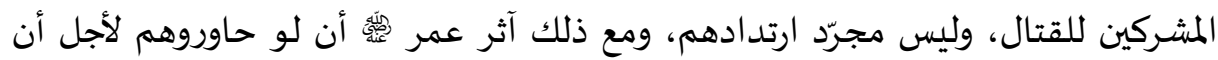

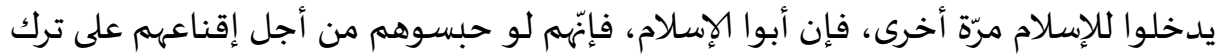
القتال لكان أفضل.

بهذا القراءة التّفسيرية التّزامنية يتّضح السّياق الحقيقي والواقعي الّّني صاحب ورود

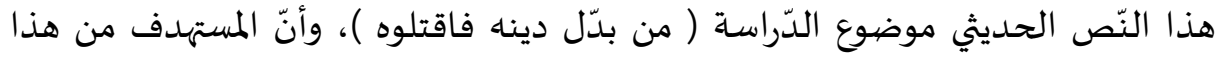

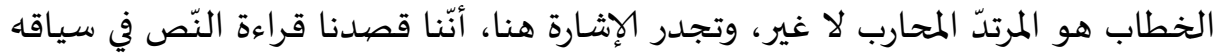

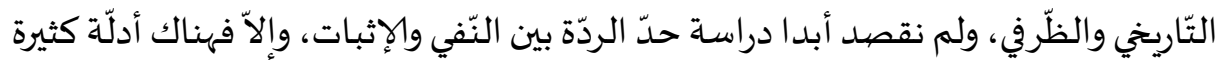


أخرى تدعم ما ذهبنا إليا،، لكنهّا لا تدعم منهجنا في هذه الدّراساة، وهي الاكتفاء بقراءة النّص وفق الظّرف الذّي ورد فيـه.

\section{ب ـ القراءة التّأويلية الإسقاطية:}

بناء على ما أسلمته لنا القراءة التّفسيرية التّزامنية، نصددر عن ملمَحِ واضِِِ ومُطَمِئن

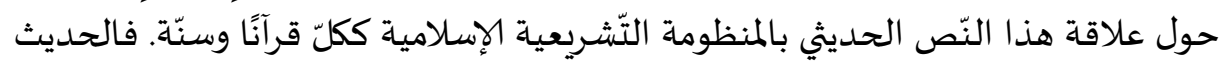

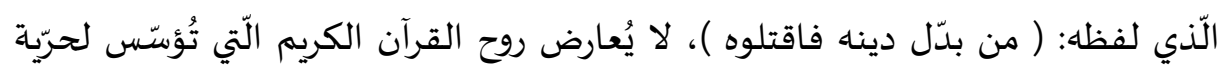

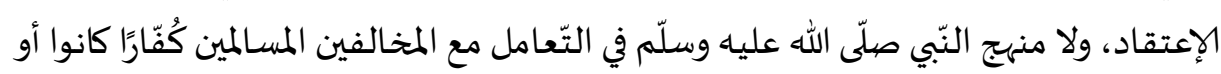

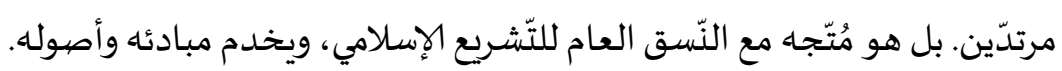
على أنّ الإسلام كما هو دين رحمة، فهو دين ملحمة كذلك، وكما هو دين الحبّ والودّ؛

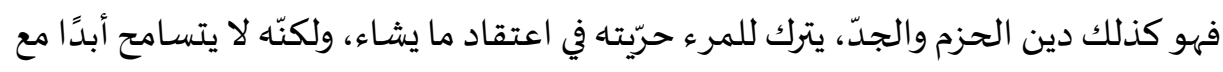

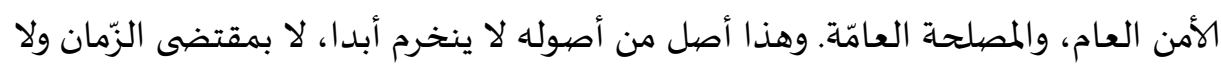

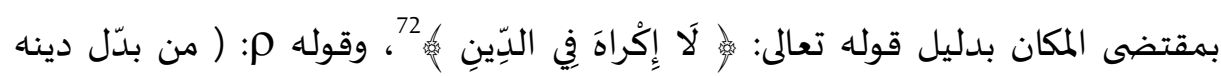

\section{خاتمة:}

بناء على كلّ ما سبق التطرّق إليه، فإنّ البحث يُسلمنا إلى النّتائج التّالية: 1 ـ أيّ محاولة لقراءة النّص الحديثي قراءة استنتاجية تأويلية، دون المرور على القراءة

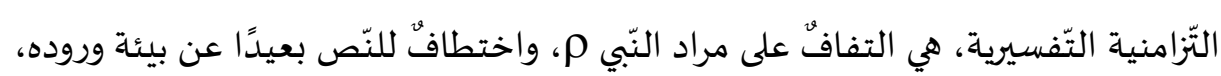
والواقع المُعيّن الّذي وُلِّنَ من أجله.

وبالتّالي فالقراءة التّزامنية للنّصّ الحديثي هي الضّامن الأساس للحفاظ على المُراد

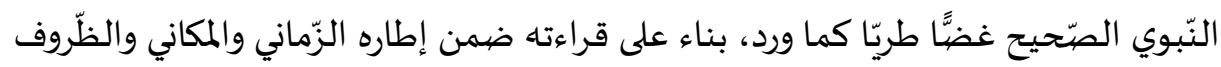

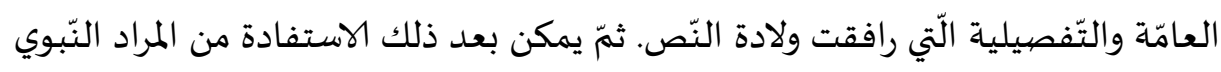

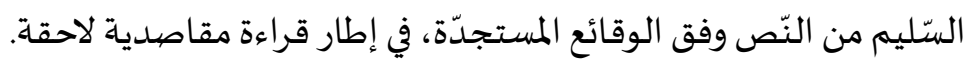

2 ـ القراءة التّاويلية المبتورة عن السّياق الظّرفي العام الّّدي وُلِد فيه النّص الحديثي،

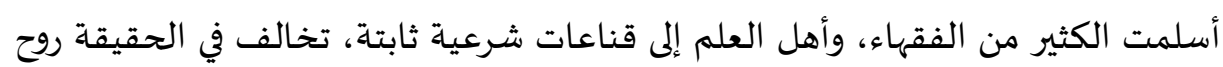

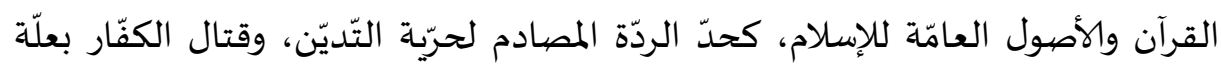


الكفر المصادم لحريّة المعتقد، والمؤسّس لمنطق الإكراه في الدّين، وكذا اعتقاد الشّوّم في

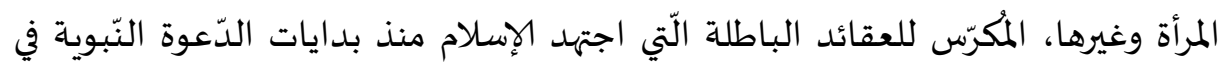
إزالهها من ذهنية المجتمع المسلم.

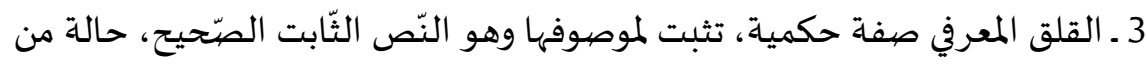

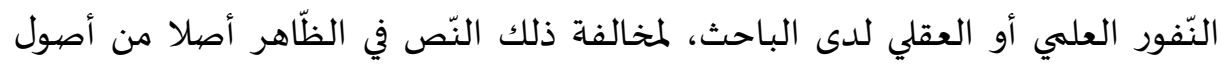
الإسلام، أو حقيقة من حقائق العلوم، أو عرفًا من أعراف البشرية المجمع على لئى صلاحها. 4 ـ ردّ الأحاديث الصّّحيحة التّي ثبتت بقواعد النّقد الحديثية المتينة علميّا، من منطلق

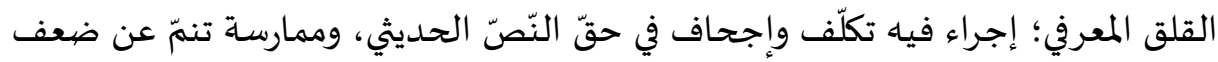

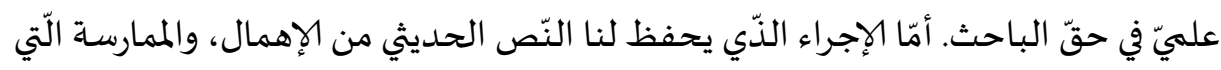

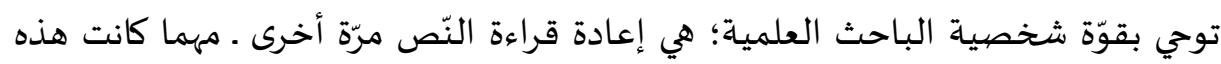

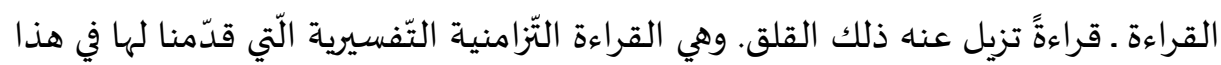
البحث.

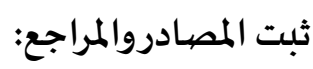

إبراهيم بن محمد، برهان الدين ابن حَمْزَة الحنفي الدمشَيّ، البيان والتعريف في أسباب ورود

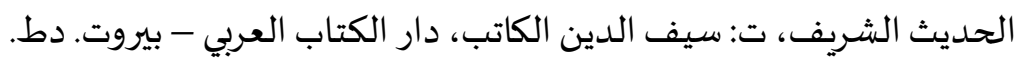

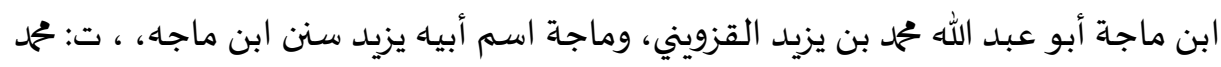

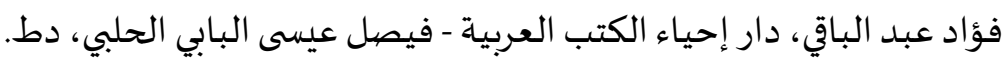
أبو العباس أحمد بن محمد شهاب الدين القسطلاني، إرشاد الساري لشرح صحيح البخاري،

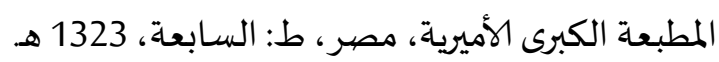

أبو العباس أحمد بن محم، ت: أحمد عبد الله القرشي رسلان، البحر المديد في تفسير القرآن

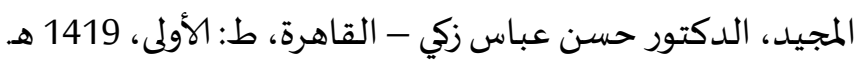

أبو الفداء إسماعيل بن عمر بن كثير، تفسير القرآن العظيم، ت: سامي بن محمد سلامة، دار

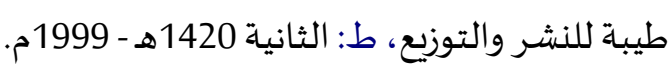




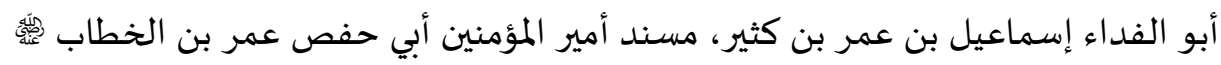

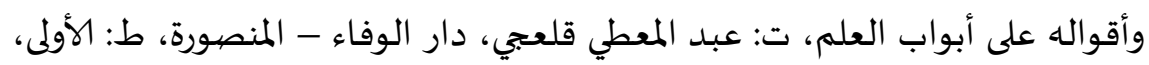
1411 - 1991م. 1991 الهو

أبو جعفر الطحاوي، ت: شعيب الأرنؤوط، شرح مشكل الآثار، مؤسسة الرسالة، ط: الأولى -

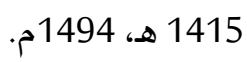

أبو جعفر محمد بن جرير الطبري، تهذيب الآثار وتفصيل الثابت عن رسول الله من الأخبار، ت:

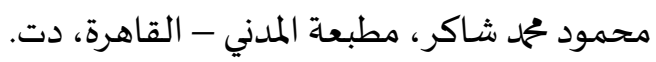

أبو داود الطيالسي، مسند أبي داود الطيالسي، دار المعرفةــبيروت، دط. أبو داود سليمان بن الأشعث السيّجِسنتاني، سنن أبي داود، ت: محمد محيي الدين عبد الحميد، المكتبة العصرية، صيدا- بيروت.

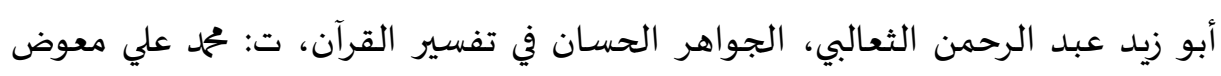

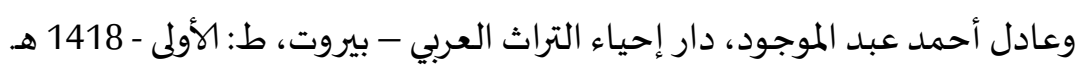
أبو سليمان أحمد بن محمد البستي المعروف بالخطابي، معالم السنن، وهو شرح سنن أبي

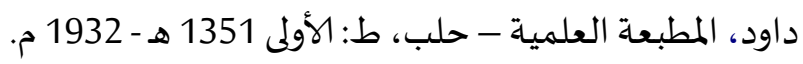

أبو عبد الرحمن أحمد بن شعيب بن علي الخراساني، النسائي، المجتبى من السنن = السنن

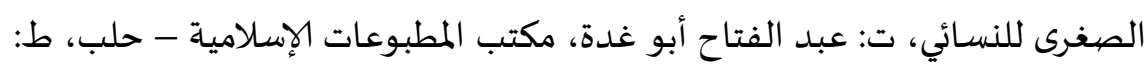

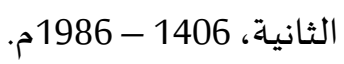

أبو عبد الرحمن محمد ناصر الدين الألباني، سلسلة الأحاديث الصحيحة وشيء من فقهها

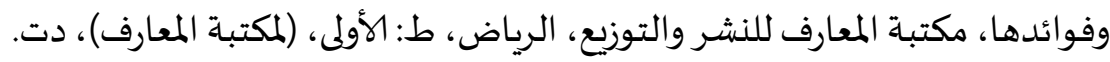
أبو عبد الله أحمد بن محمد بن حنبل الشيباني، مسند الإمام أحمد بن حنبل، ت: شعيب

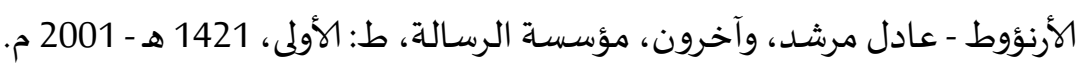

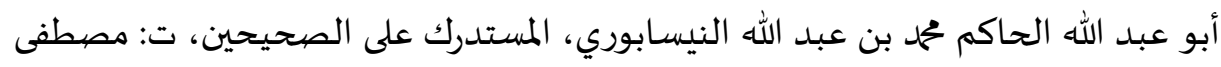

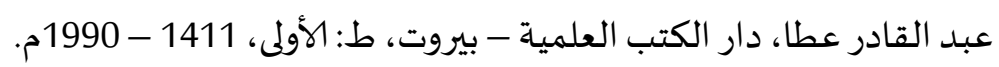


أبو عبد الله محمد شمس الدين، الجامع لأحكام القرآن = تفسير القرطبي، ت: أحمد البردوني وإبراهيم أطفيش، دار الكتب المصرية - القاهرة، ط: الثانية، 1384هـ - 1384 - 1964 م.

أبو عبد الله محمد فخر الدين الرازي، مفاتيح الغيب = التفسير الكبير، دار إحياء التراث العربي - بيروت، ط: الثالثة - 1420 هـ

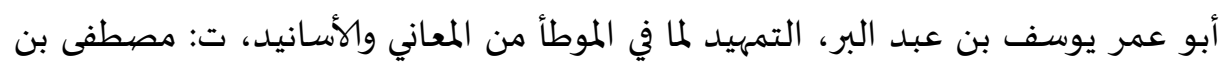

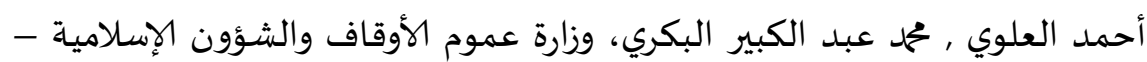

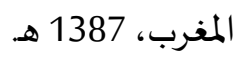

أبو محمد عبد الحق بن عطية، المحرر الوجيز في تفسير الكتاب العزيز، ت: عبد السلام عبد

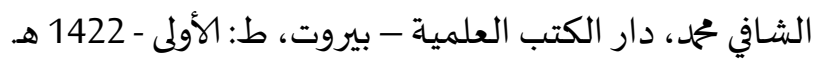

أبو محمد عبد الله بن مسلم بن قتيبة الدينوري، تأويل مختلف الحديث، المكتب الاسلامي -

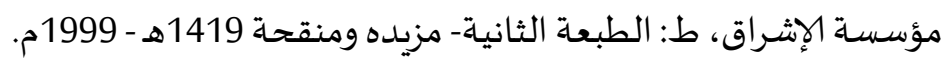

أبو محمد موفق الدين عبد الله بن قدامة المقدسي، المغني لابن قدامة، مكتبة القاهرة، دط.

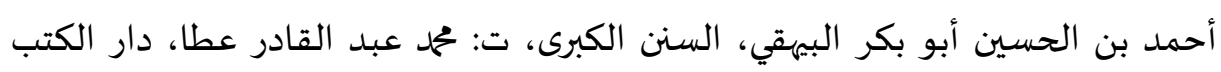

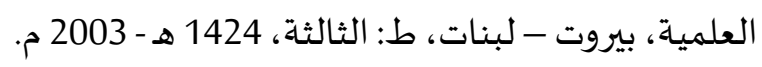

تقي الدين أبو الفتح محمح ابن دقيق العيد، شرح الأربعين النووية في الأحاديث الصحيحة

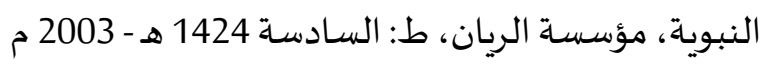

حكمت بن بشير بن ياسين، موسوعة الصّحيح المسبور من التفسير بالمأثور، دار المآثر للنشر

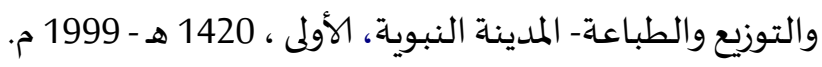

زين الدين عبد الرحمن بن رجب الحنبلي، جامع العلوم والحكم في شرح خمسين حديثا من

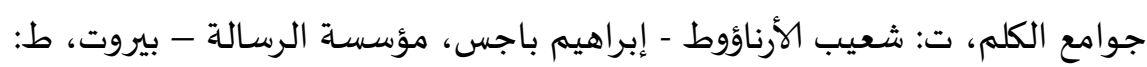

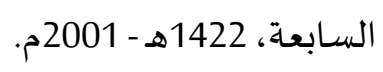

سليمان بن أحمد أبو القاسم الطبراني، مسند الشاميين، ت: حمدي بن عبدالمجيد السلفي،

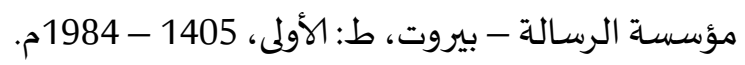


سليمان بن أحمد الطبراني، المعجم الأوسط، ت: طارق الحسيني، دار الحرمين ـ القاهرة، 1415هـ

شمس الدين، أبو العون محمد بن أحمد بن سالم السفاريني الحنبلي، لوامع الأنوار الهية

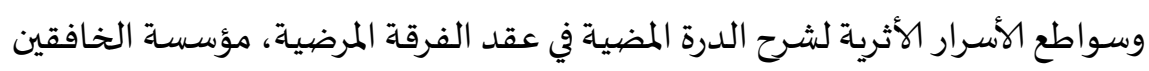
ومكتبتها - دمشق، ط: الثانية - 1402 هـ - 1982 م.

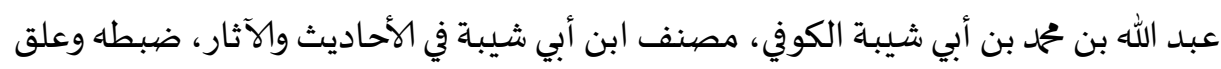

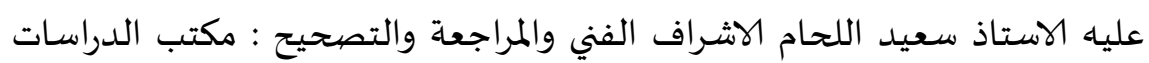
والبحوث في دار الفكر ـ دار الفكر.

عدد من المختصين بإشراف الشيخ/ صالح بن عبد الله بن حميد، نضرة النعيم في مكارم

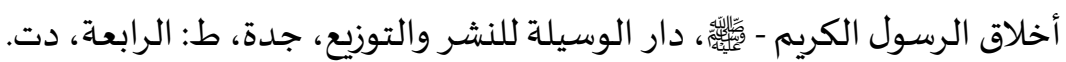

علي بن (سلطان) محمد، أبو الحسن نور الدين الملال الهروي القاري، مرقاة المفاتيح شرح مشكاة

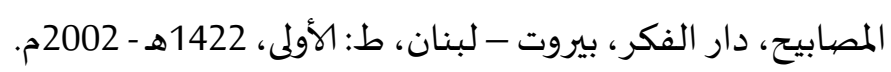

مالك بن أنس بن مالك بن عامر الأصبحي المدني، موطأ الإمام مالك، صححها ورقمه وخرج

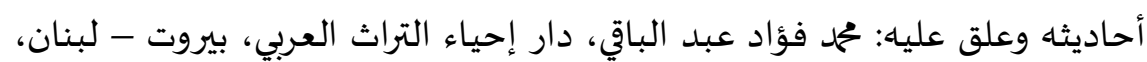
1406 هـ - 1985 م. 1985

محمد الأمين بن محمد المختار الشنقيطي، أضواء البيان في إيضاح القرآن بالقرآن، دار الفكر

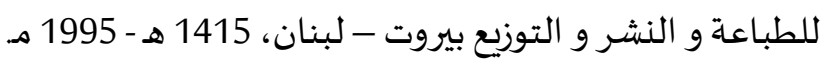

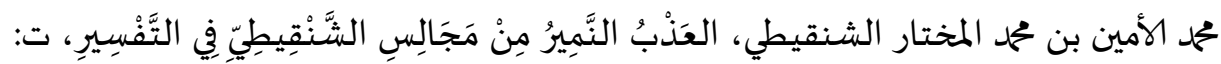

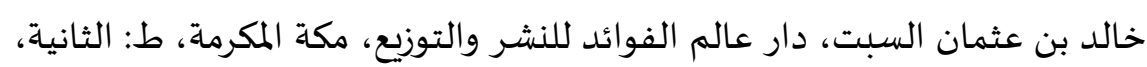
1426 هـ

محمد الطاهر بن عاشور، التحرير والتنوير "تحرير المعنى السديد وتنوير العقل الجديد من تفسير الكتاب المجيد《، الدار التونسية للنشر - تونس: 1984 هـ

محمد أنور شاه بن معظم شاه الكشميري الهندي، العرف الشذي شرح سنن الترمذي، تصحيح:

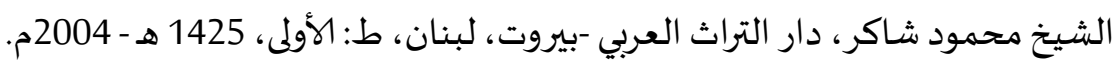




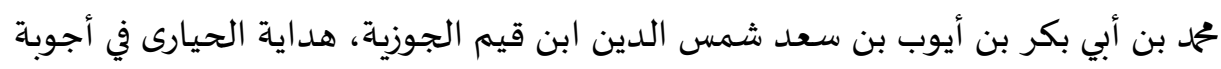

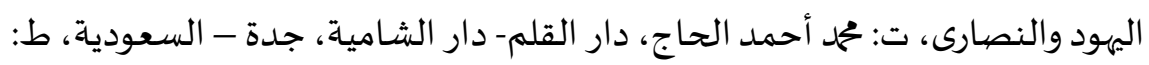

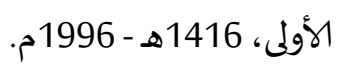

محمح بن أبي بكر شمس الدين ابن قيم الجوزية، مفتاح دار السعادة ومنشور ولاية العلم

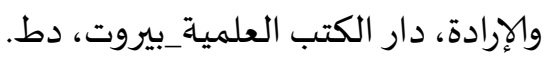

محمح بن أحمد ابن جزي، ت: الدكتور عبد الله الخالد، التسهيل لعلوم التنزيل، أبو القاسم،

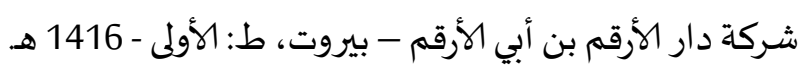

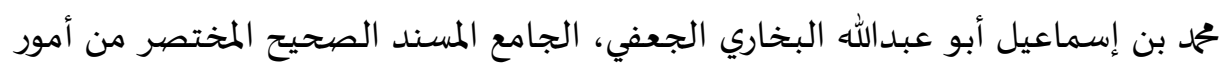

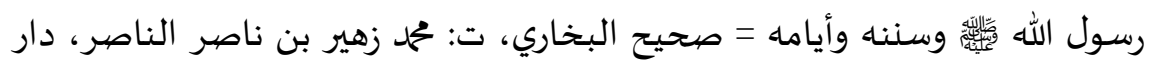

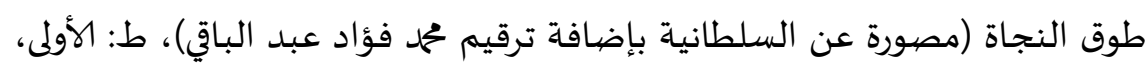
1422

محمد بن صالح بن محمد العثيمين، شرح رياض الصالحين، دار الوطن للنشر، الرياض، ط: 1426

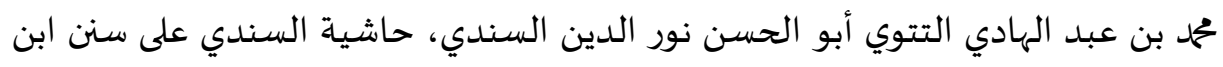

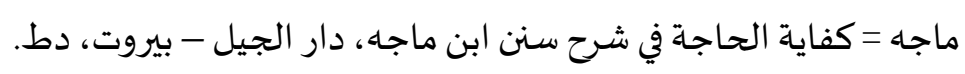

محمد بن عيسى بن سَوْرة بن موسى بن الضحاك، الترمذي، أبو عيسى، سنن الترمذي، ت:

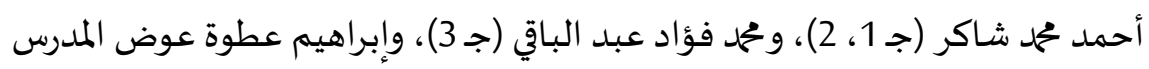

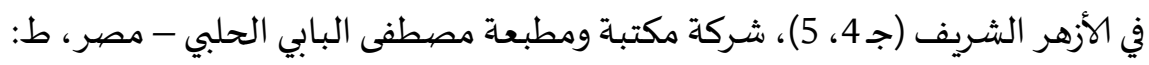

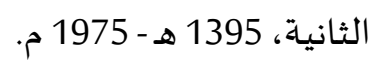

محمح جمال الدين القاسمي، محاسن التأويل، ت: محمد باسل عيون السود، دار الكتب العلمية

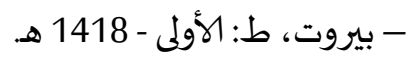

محمد رشيد بن علي رضا، تفسير القرآن الحكيم (تفسير المنار)، الهيئة المصرية العامة للكتاب: 1990م. 
محمد علي بن علان البكري، دليل الفالحين لطرق رياض الصالحين، دار المعرفة للطباعة

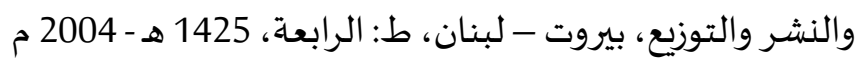

مسلم بن الحجاج أبو الحسن القشيري النيسابوري، المسند الصحيح المختصر بنقل العدل

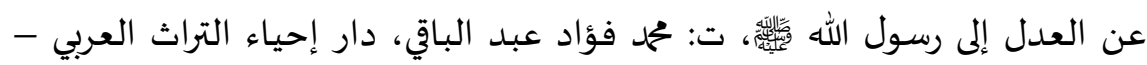

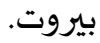

رواه البخاري، كتاب الإيمان، باب: (فإن تابوا وأقاموا الصلاة وآتوا الزكاة فخلوا سبيلهمأ، رقم: 25.

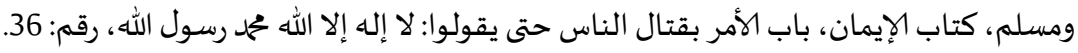

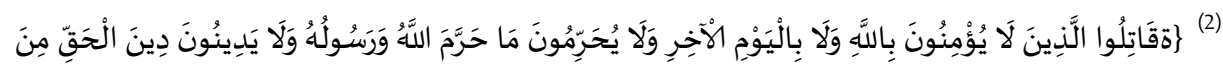

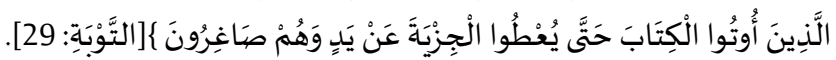

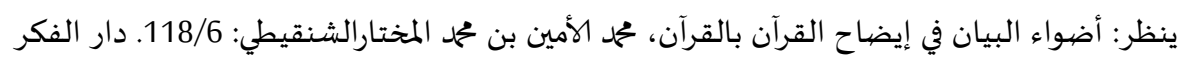

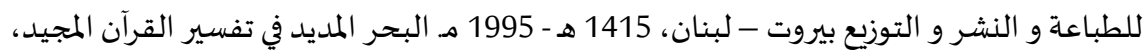

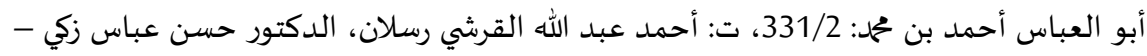

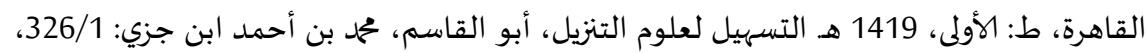

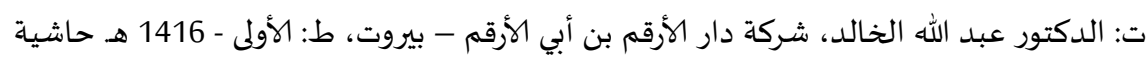

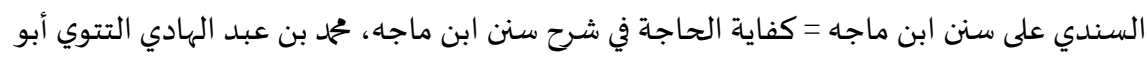

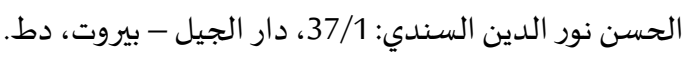

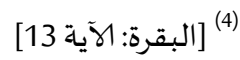

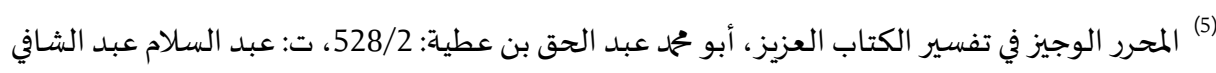

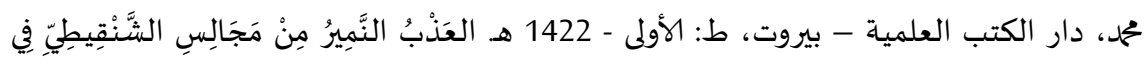

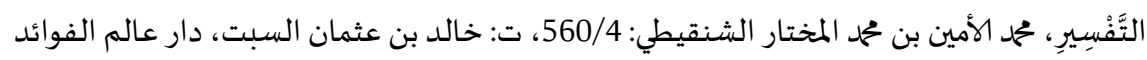

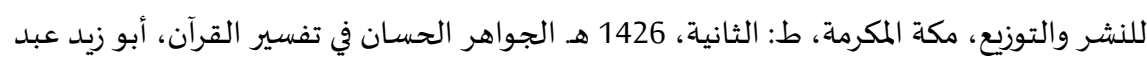


الرحمن الثعالبي: 133/3، ت: محمد علي معوض وعادل أحمد عبد الموجود، دار إحياء التراث العربي -

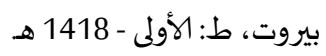

الجامع لأحكام القرآن = تفسير القرطبي، أبو عبد الله محمد شمس الدين: 353/2، ت: أحمد البردوني

وابراهيم أطفيش، دار الكتب المصرية - القاهرة، ط: الثانية، 1384هـ - 1964 م.

شرح رياض الصالحين، محمد بن صالح بن محمد العثيمين: 95/5، دار الوطن للنشر، الرياض، ط: 1426 هـ

$$
\text { (8) ينظر: أضواء البيان: 449/3. }
$$

(9) دليل الفالحين لطرق رياض الصالحين، محمل علي بن علان البكري: 10/7، دار المعرفة للطباعة والنشر والتوزيع، بيروت - لبنان، ط: الرابعة، 1425 هـ - 2004 م.

$$
\begin{aligned}
& \text { [10) } \\
& \text { [الكافرون:6) } \\
& \text { (12) } \\
& \text { (13) [الشورى:48] } \\
& \text { [14) }
\end{aligned}
$$

ينظر: إرشاد الساري لشرح صحيح البخاري، أبو العباس أحمد بن محمد شهاب الدين القسطلاني:

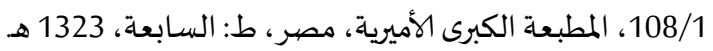

$$
\text { سنن النّسائي، كتاب تحريم الدّم، رقم: } 3966 .
$$

معالم السنن، وهو شرح سنن أبي داود، أبو سليمان أحمد بن محمد البستي المعروف بالخطابي: 11/2،

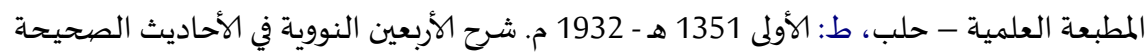

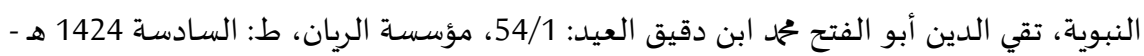

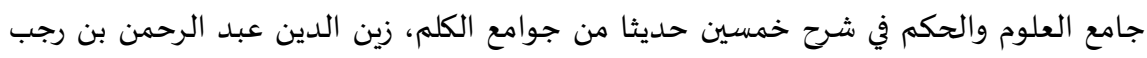

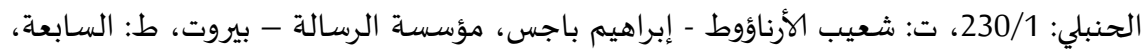


ينظر: موسوعة الصّّحيح المسبور من التفسير بالمأثور: 301/1، حكمت بن بشير بن ياسين، دار المآثر

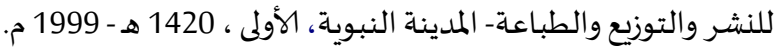

مفاتيح الغيب = التفسير الكبير، أبو عبد الله محمد فخر الدين الرازي: 483/15، دار إحياء التراث العربي - بيروت، ط: الثالثة - 1420 هـ تفسير القرآن العظيم، أبو الفداء إسماعيل بن عمر بن كثير: 526/1، ت: سامي بن محمد سلامة، دار طيبة للنشر والتوزيع، ط: الثانية 1420هـ - 1999 م.

$$
\text { ابن كثير: 56/4 }
$$

محاسن التأويل، محمل جمال الدين القاسمي: 59/2، ت: محمل باسل عيون السود، دار الكتب العلميه ــ

$$
\text { بيروت، ط: الأولى - } 1418 \text { هـ نـاني }
$$

مصنف ابن أبي شيبة في الأحاديث والآثار، عبد الله بن محمد بن أبي شيبة الكوفي: 57/11، ضبطه وعلق

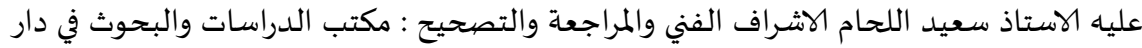

البيان والتعريف في أسباب ورود الحديث الشريف، إبراهيم بن محم، برهان الدين ابن حَمْزَة الحنفي

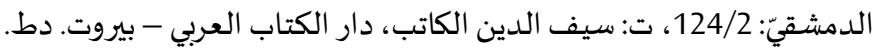

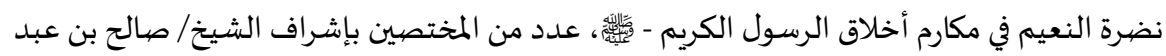

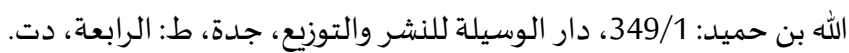

هداية الحيارى في أجوبة اليهود والنصارى، محمد بن أبي بكر بن أيوب بن سعد شمس الدين ابن قيم

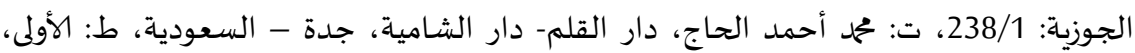
1416هـ - 1996م

العرف الشذي شـرحسنن الترمذي، محمد أنور شاه بن معظم شاه الكشميري الهندي: 207/1، تصحيح: الشيخ محمود شاكر، دار التراث العربي -بيروت، لبنان، ط: الأولى، 1425 هـ - 2004 م.

$$
\text { رواه البخاري، كتاب النّكاح، باب ما يتقى من شؤم المرأة...، رقم: } 5093 .
$$

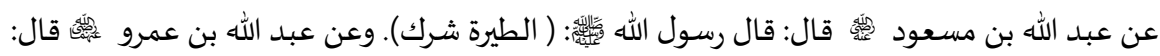

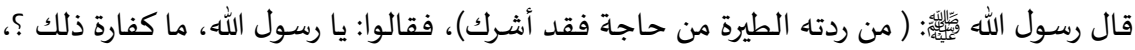

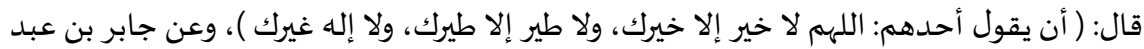

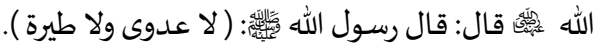


صحيح، ينظر: الموطتّأ، كتاب الاستئذان، باب: ما يُتقى من الشؤم، رقم الحديث: 1538. البخاري، كتاب:

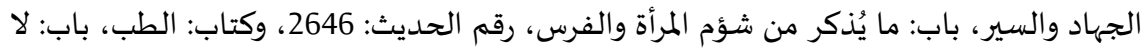

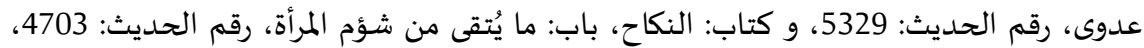

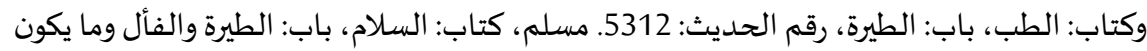

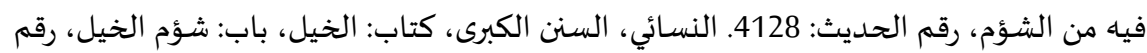

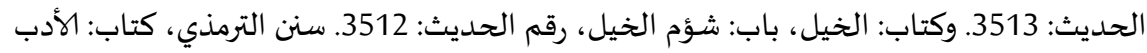

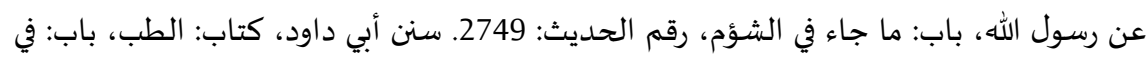

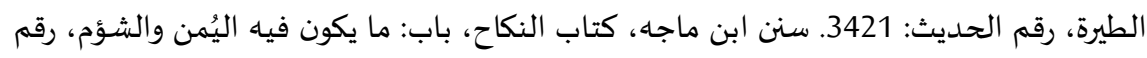

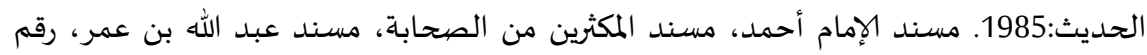

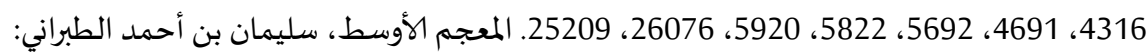
279/7، ت: طارق الحسيني، دار الحرمين ـ القاهرة، 1415هـ مسند أبي داود الطيالسي، أبو داود الطيالسي: 215/1، دار المعرفةـ بيروت، دط.

صحيح، ينظر: موطأ الإمام مالك، كتاب الاستئذان، باب: ما يُتقى من الشؤم، رقم الحديث: 1537. (34)

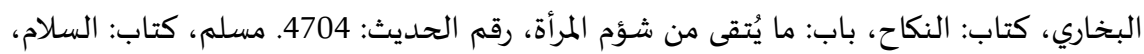

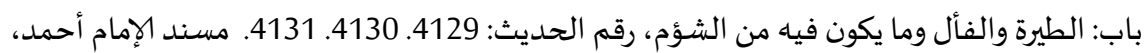
باقي مسند الأنصار، حديث أبي مالك سهل بن سعد الساعدي، رقم الحديث: 21769، 21796. 217. وفي

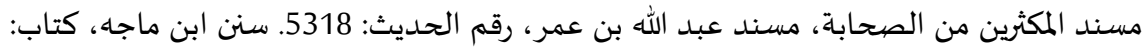

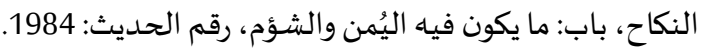

أخرجه الطبّراني في مسند الشـاميين، سليمان بن أحمد أبو القاسم الطبراني، رقم: 3505، 342/4، ت: (35)

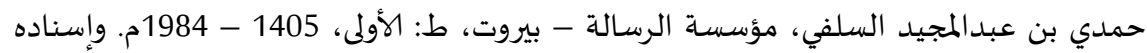

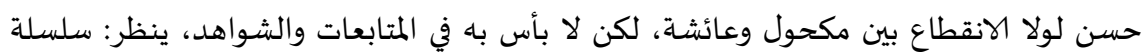

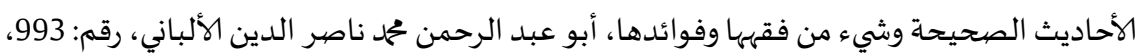
690/2، مكتبة المعارف للنشر والتوزيع، الرياض، ط: الأولى، (لمكتبة المعارف). إسناده صحيح على شرط مسلم. أبو حسان - وهو الأعرج - من رجاله، وبقية رجاله ثقات رجال

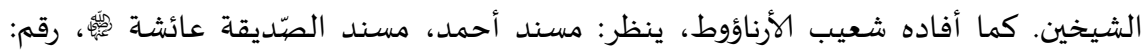
26088، 197/43. وأخرجه الحاكم في المستدرك على الصحيحين، كتاب التفسير، تفسير سورة

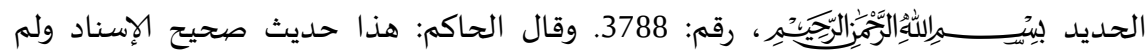
يخرجاه، ووافقه الذّهبي. قال الألباني: وهو كما قالا، بل هو على شرط مسلم، فإن أبا حسان هذا

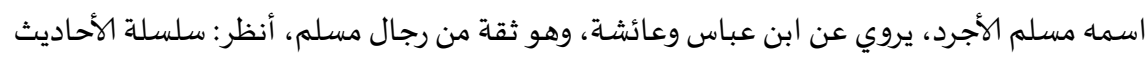


الصحيحة ، محم ناصر الدين الألباني، رقم: 693، 690/2. دت. السنن الكبرى للبيهي، كتاب القسامة، باب العيافة والطيرة والطرق، رقم: 16525. مسند الشاميين، رقم: 2702، 50/4. تأويل

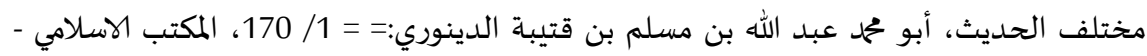

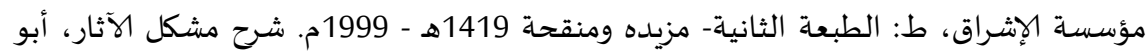

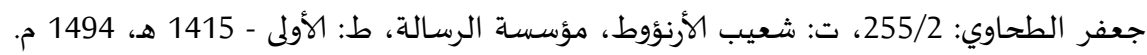

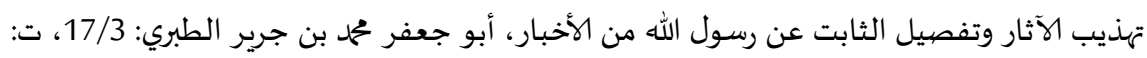

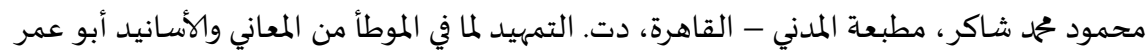
يوسف بن عبد البر: 288/9 ـ 290، ت: مصطفى بن أحمد العلوي , محمد عبد الكبير البكري، وزارة

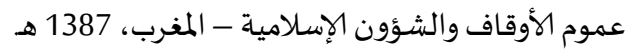

ينظر: التمهيد لما في الموطأ من المعاني والأسـانيد أبو عمر يوسف بن عبد البر، مصدر سابق: 289/9. رواه البخاري، كتاب الطّب، باب الجذام، رقم: 5707. ومسلم، كتاب السلام، باب الطيرة والفأل وما

$$
\text { يكون فياء من الشؤم، رقم: } 2223 .
$$

$$
\text { مسند أحمد، مسند أبي هريرة لَّلَّ، رقم: 7883، 265/13. }
$$

$$
\text { سلسلة الأحاديث الصحيحة ، محمد ناصر الدين الألباني، رقم: 442، 804/1. }
$$

مفتاح دار السعادة ومنشور ولاية العلم والإرادة، محمد بن أبي بكر شمس الدين ابن قيم الجوزية:

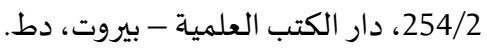

إرشاد الساري لشرح صحيح البخاري، شهاب الدين القسطلاني، مرجع سابق: 24/8. مرقاة المفاتيح

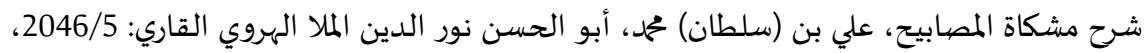

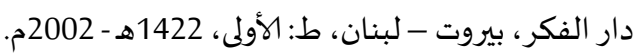

رواه البخاري، كتاب/ستتابة المرتدين والمعاندين وقتالهم، باب حكم المرتد والمرتدة واستتابتهم، رقم:

$$
\begin{aligned}
& \text { [آل عمران: } \\
& \text { [آل عمران: 100] }
\end{aligned}
$$


$\left[54:{ }^{(50)}\right.$

[106: (51)

[البقرة: 217

(53) رواه البخاري، كتاب الجهاد والسيّير، باب: لا يعذب بعذاب الله، رقم: 3017.

سنن الترمذي، كتاب عن رسول الله صلى الله عليه وسلّم، باب ما جاء في المرتد، رقم: 1458. سنن البيهقي، باب قتل من ارتد عن الإسلام رجلا كان أو امرأة، رقم: 3165، 278/3.

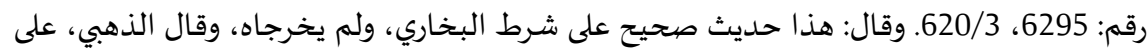

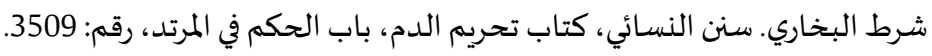

رواه البخاري، كتاب استتابة المرتدين والمعاندين وقتالهم، باب حكم المرتد والمرتدة واستتابتهم، رقم:

6922

ينظر: المغني لابن قدامة، أبو محمل موفق الدين عبد الله بن قدامة المقدسي: 370/6، مكتبة القاهرة،

دط.

[النساء: 145 - 146]

لوامع الأنوار الهياة وسواطع الأسرار الأثرية لشرح الدرة المضية في عقد الفرقة المرضية، شمس الدين،

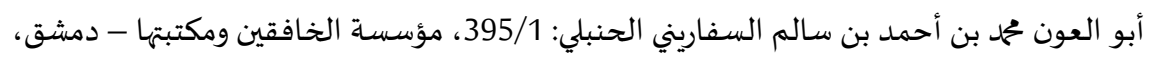
ط: الثانية - 1402 هـ - 1982 م.

التحرير والتنوير "تحرير المعنى السديد وتنوير العقل الجديد من تفسير الكتاب المجيده، محمد الطاهر بن عاشور: 231/5، الدار التونسية للنشر - تونس: 1984 هـ

[88: (60)

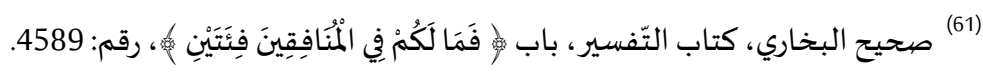
(62) التحرير والتنوير، الطّاهر بن عاشور: 150/5. رواه البخاري، كتاب الأحكام، باب من بايع ثن استقال البيعة، رقم: 7211، ومسلم، كتاب الحج، باب المدينة تنفي شرارها، رقم: 1383.

صحيح البخاري، كتاب الغسل، باب الجنب يخرج ويمشي في السوق وغيره، رقم: 285. ومسلم، كتاب الحيض، باب الدليل على أن المسلم لا ينجس، رقهم: 371.

NÜSHA, 2018; (47):269-308 
[النساء: (65)

تفسير القرآن الحكيم (تفسير المنار)، محمد رشيد بن علي رضا: 376/5، الهيئة المصرية العامة للكتاب:

1990 م.

$$
\text { سنن أبي داود، كتاب الحدود، باب الحكم فيمن ارتد، رقم: } 4353 .
$$

صحيح، رواه التّرمذي في سننه، كتاب الحدود عن رسول الله صلّى الله عليه وسلم، باب ما جاء في المرتدّ،

$$
\text { رقم: } 1458 .
$$

الجامع لأحكام القرآن = تفسير القرطبي، أبو عبد الله محمد بن أحمد شمس الدين القرطبي: 48/3، ت:

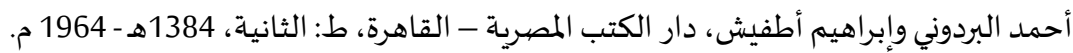

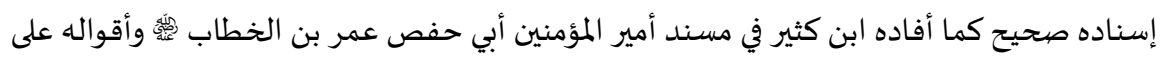

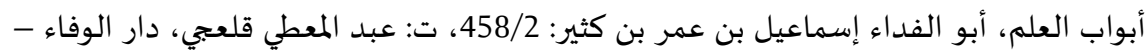

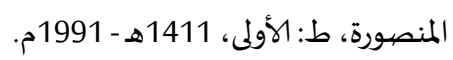

